\title{
Endoscopic diagnosis and therapies for Barrett esophagus. A review
}

\author{
Irving Waxman ${ }^{1}$, Mariano González-Haba-Ruiz ${ }^{2}$ and Enrique Vázquez-Sequeiros ${ }^{3}$
}

${ }^{I}$ Center for Endoscopic Research and Therapeutics. University of Chicago Medical Center. Chicago, IL. USA. ${ }^{2}$ Servicio de Gastroenterología y Hepatología. Hospital Universitario Puerta de Hierro Majadahonda. Madrid, Spain. ${ }^{3}$ Endoscopy Unit. Department of Gastroenterology. Hospital Universitario Ramón y Cajal. Universidad de Alcalá, IRYCIS. Madrid, Spain

\begin{abstract}
Barrett's esophagus is an area of great interest in Gastroenterology, with an increasing number of research studies being published in recent years and decades. Due to the fast growing evidence regarding this disease, it has become extremely difficult to keep updated on this subject. The present review article aims to summarize and update what is known regarding diagnosis and therapy in Barrett's esophagus. A critical and detailed review is made and the role of surveillance for this condition, techniques available for diagnosis (standard white light endoscopy, virtual chromoendoscopy, magnification...) and treatment (mucosectomy, ablation...) are presented. New and emerging technologies are described in detail and existing evidence is presented.
\end{abstract}

Key words: Barrett. Esophagus. Endoscopy. Dysplasia. Mucosectomy. Radiofrequency.

\section{INTRODUCTION}

Esophageal adenocarcinoma (EAC) has been increasing in the United States more than six-fold over the past three decades, faster than that of any other malignancy (1). Barrett esophagus (BE) is a well-established precursor of EAC and increases the risk of developing EAC by greater than 40-fold compared with the general population (2).

$\mathrm{BE}$ is currently defined as "the condition in which any extent of metaplastic columnar epithelium that

Waxman I, González-Haba-Ruiz M, Vázquez-Sequeiros E. Endoscopic diagnosis and therapies for Barrett esophagus. A review. Rev Esp Enferm Dig 2014;106:103-119.

Received: 21-01-2014

Accepted: 10-02-2014

Correspondence: Enrique Vázquez-Sequeiros. Endoscopy Unit. Department of Gastroenterology. Hospital Universitario Ramón y Cajal. Ctra. de Colmenar Viejo, km. 9,100. 28034 Madrid, Spain

e-mail: evazquezse@gmail.com predisposes to cancer development replaces the stratified squamous epithelium that normally lines the distal esophagus" (3). Currently, only the presence of specialized columnar epithelium containing goblet cells is required for establishing a diagnosis of $\mathrm{BE}$, prior to recommendations of surveillance, as it has been considered to be the only type of epithelium that clearly predisposes to malignancy (4).

But there is not a universal agreement for including intestinal metaplasia (IM) as a requisite for the diagnosis of BE. Non-goblet columnar metaplasia by itself also seems to predispose to cancer, but the true magnitude of this risk is unknown (5-9).

Dysplasia can be defined as the presence of neoplastic epithelium that is confined within the basement membrane of the gland within which it arises. The grading of dysplasia is critical in stratifying the risk of developing subsequent cancer in patients with Barrett's esophagus, and to date, it is the most important predictive marker for the development of invasive adenocarcinoma (10).

But grading of dysplasia is sometimes difficult, leading to disagreement among pathologists in the histological interpretation of the endoscopy specimens, especially in the low spectrum of dysplasia (Non Dysplastic Barrett Esophagus $\{\mathrm{NDBE}\}$; and Low Grade Dysplasia $\{\mathrm{LGD}\})$ (11-13).

\section{RISK OF PROGRESSION AND ENDOSCOPIC SURVEILLANCE}

The identification of early-stage cancer, when treatment is most effective, is the basis for all surveillance recommendations (14-16). Guidelines proposed by the principal societies provide different intervals for surveillance depending on the grade of dysplasia detected on pathology specimens (17-20) (Table I). 
Table I. Recommendations on surveillance for Barrett esophagus according to the following societies: ACG: American College of Gastroenterology; ASGE: American Society of Gastrointestinal Endoscopy; AGA: American Gastroenterological Association; and BSG: British Society of Gastroenterology

\begin{tabular}{|c|c|c|c|c|}
\hline & ACG 2008 (17) & $\begin{array}{c}\text { ASGE } 2012 \text { (19) } \\
\text { ASGE } \\
\text { ASGEm }\end{array}$ & 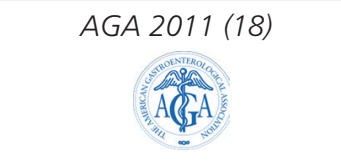 & 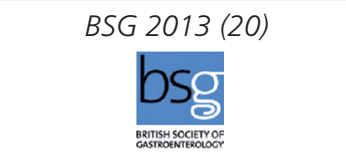 \\
\hline $\begin{array}{l}\text { Non dysplastic BE } \\
\text { (NDBE) }\end{array}$ & $\begin{array}{l}\text { Two EGDs with biopsy } \\
\text { within } 1 \text { year } \\
\text { Follow up every } 3 \text { years }\end{array}$ & $\begin{array}{l}\text { Consider no surveillance. } \\
\text { EGD every } 3 \text { to } 5 \text { years } \\
\text { Consider endoscopic ablation } \\
\text { in select cases }\end{array}$ & EGD every 3 to 5 years & $\begin{array}{l}\text { SSBE with no IM - } \\
\text { Consider discharge } \\
\text { SSBE with IM - EGD every } \\
3 \text { to } 5 \text { years } \\
\text { LSBE - EGD every } 2 \text { to } 3 \\
\text { years }\end{array}$ \\
\hline $\begin{array}{l}\text { Indefinite for } \\
\text { dysplasia (IDBE) }\end{array}$ & & $\begin{array}{l}\text { Expert pathologist review } \\
\text { Repeat EGD with maximal } \\
\text { acid suppression }\end{array}$ & & $\begin{array}{l}\text { Repeat EGD at } 6 \text { months } \\
\text { with maximal acid } \\
\text { suppression } \\
\text { If IDBE survey as NDBE }\end{array}$ \\
\hline $\begin{array}{l}\text { Low grade dysplasia } \\
\text { (LGD) }\end{array}$ & $\begin{array}{l}\text { Expert pathologist } \\
\text { confirmation }\end{array}$ & $\begin{array}{l}\text { Expert pathologist } \\
\text { confirmation }\end{array}$ & $\begin{array}{l}\text { Expert pathologist } \\
\text { confirmation }\end{array}$ & $\begin{array}{l}\text { Expert pathologist } \\
\text { confirmation }\end{array}$ \\
\hline & $\begin{array}{l}\text { Highest grade on repeat } \\
\text { EGD with biopsies within } \\
6 \text { months } \\
\text { Follow up every year }\end{array}$ & $\begin{array}{l}\text { Repeat EGD in } 6 \text { months to } \\
\text { confirm LGD } \\
\text { Follow up every year, } \\
\text { Consider endoscopic } \\
\text { resection or ablation }\end{array}$ & $\begin{array}{l}\text { Follow up every 6-12 } \\
\text { months } \\
\text { Consider endoscopic } \\
\text { eradication therapy (RFA) }\end{array}$ & $\begin{array}{l}\text { Follow up every } 6 \text { months } \\
\text { Ablation therapy cannot } \\
\text { be recommended } \\
\text { routinely until data from } \\
\text { RCTs are available }\end{array}$ \\
\hline \multirow[t]{2}{*}{$\begin{array}{l}\text { High grade dysplasia } \\
\text { (HGD) }\end{array}$} & $\begin{array}{l}\text { Expert pathologist } \\
\text { confirmation } \\
\text { Repeat EGD with biopsies } \\
\text { within } 3 \text { months }\end{array}$ & $\begin{array}{l}\text { Expert pathologist } \\
\text { confirmation } \\
\text { Consider EMR or RFA } \\
\text { Consider surgical consultation }\end{array}$ & $\begin{array}{l}\text { Expert pathologist } \\
\text { confirmation } \\
\text { Mucosal irregularity EMR }\end{array}$ & $\begin{array}{l}\text { Expert pathologist } \\
\text { confirmation } \\
\text { Mucosal irregularity EMR }\end{array}$ \\
\hline & $\begin{array}{l}\text { Mucosal irregularity EMR } \\
\text { Continued } 3 \text { month } \\
\text { surveillance } \\
\text { Endoscopic therapy } \\
\text { Esophagectomy }\end{array}$ & $\begin{array}{l}\text { Consider surveillance EGD } \\
\text { every } 3 \text { months (only } \\
\text { patients non candidates } \\
\text { for endoscopic or surgical } \\
\text { approach) }\end{array}$ & $\begin{array}{l}\text { Endoscopic eradication } \\
\text { therapy (RFA, PDT } \\
\text { or EMR) rather than } \\
\text { surveillance or surgery } \\
\text { Continued } 3 \text { month } \\
\text { surveillance } \\
\text { Esophagectomy only in } \\
\text { specialized surgical centers }\end{array}$ & $\begin{array}{l}\text { Endoscopic therapy } \\
\text { is preferred over } \\
\text { esophagectomy } \\
\text { or endoscopic surveillance }\end{array}$ \\
\hline
\end{tabular}

EGD: Esophagogastroduodenoscopy; EMR: Endoscopic mucosal resection; RFA: Radiofrequency ablation; PDT: Photodynamic therapy; SSBE: Short segment Barrett's esophagus; LSBE: Long segment Barrett's esophagus; IM: Intestinal metaplasia. RCTs: Randomized control trials.

\section{Non dysplastic Barrett esophagus (NDBE)}

Data from two recent population studies and a recent meta-analysis found that the cancer risk in BE is around $0.1-0.3 \%$ per year $(8,9,21)$ much lower than the previously assumed risk of $0.5 \%$ year. A recent multicenter study showed that persistence of NDBE, based on multiple surveillance endoscopies, was associated with a gradually lower likelihood of progression to EAC (22).

Recent publications on mortality and cost effectiveness (23-28) bring into question about the rationale for ongoing surveillance in patients with NDBE, and support the search for valid risk stratification tools to identify the minority of patients that are likely to benefit.

\section{Low grade dysplasia (LGD)}

There is controversy regarding management of LGD in Barrett esophagus, as the natural history of LGD is still poorly understood. Recent studies have calculated that the rate of progression of LGD to High Grade Dysplasia (HGD) or cancer to be $0.44 \%-0.51 \%$ per year, which is not substantially higher than $\operatorname{NDBE}(21,29)$. 
In an interesting study the histopathology reports of all patients diagnosed with LGD between 2000 and 2006 in six non-university hospitals were reviewed by two expert pathologists. After pathology review, $85 \%$ of the patients were downstaged to NDBE. In patients with a consensus diagnosis of LGD the cumulative risk of progressing to HGD or cancer was $85.0 \%$ in 109.1 months vs. $4.6 \%$ in 107.4 months for the downstaged group $(\mathrm{p}<0.0001)$ and the incidence rate of HGD or cancer was $13.4 \%$ per patient per year, vs. $0.49 \%$ in the downstaged group. According to this, LGD in BE might be overdiagnosed and yet underestimated in general practice and when this diagnosis is confirmed, patients are at much higher risk than previously reported of developing HGD/EAC (30).

For patients with LGD, a confirmation diagnosis by a second pathologist is encouraged. When confirmed, surveillance endoscopy should be performed every 6-12 months. Both the American Gastroenterological Association (AGA) and American Society for Gastrointestinal Endoscopy (ASGE) recommend considering Radiofrequency Ablation (RFA) as a therapeutic option for patients with confirmed LGD in their more recent guidelines $(18,19)$.

\section{High grade dysplasia (HGD)}

The risk of progression to adenocarcinoma among patients with HGD is approximately 6.6 cases per 100 patient-years (31). The purpose of surveillance in patients with HGD is to detect foci of intramucosal carcinoma (IMC) or EAC. Because safe and effective methods of endoscopic treatment of HGD and early EAC have emerged, continued surveillance should be offered only to patients unfit or unwilling to undergo operative or ablative therapy (19). Endoscopic management of HGD is discussed separately on this review.

\section{ENDOSCOPIC DIAGNOSIS}

The key of early diagnosis of esophageal adenocarcinoma is the detection of neoplasia arising in Barrett's esophagus. Visible lesions in the setting of HGD are at high risk of harboring cancer until proven otherwise. The recognition of subtle lesions will enable the detection of disease. Traditionally, the detection of dysplasia is based upon random four-quadrant biopsies protocol obtained every $1-2 \mathrm{~cm}$ in the Barrett segment (Seattle protocol) (32) which increases the detection of early neoplastic lesions when compared with randomly obtained biopsy specimens $(33,34)$.

But this protocol is consuming, costly and subject to a considerable sampling error, as only a tiny fraction of the "at risk" Barrett's mucosa is sampled. In general practice, adherence to this protocol is poor (30\%-79\%) which significantly decreases the rate of detecting dysplasia (35-37).

In order to improve the accuracy of endoscopic diagnosis, several endoscopic imaging techniques have been developed and tested recently. Potentially advantages of these imaging technologies include increased rates for the detection of high-risk lesions, the ability to target biopsies and resections, decreased total number of biopsies and costs for surveillance, and the ability to guide therapy in real-time.

\section{High resolution white light endoscopy (HRE)}

Detailed white light endoscopy (WLE) is the cornerstone in the detection of neoplasia in BE. Modern video endoscopes can be coupled with high-resolution technology, magnification devices and high definition screens. HRE appears to have higher sensitivity for detecting early neoplastic lesions in BE compared with standard endoscopy (38-40).

A careful WLE examination with HRE examination of the entire area of metaplasia is nowadays the standard of care for endoscopic surveillance of BE (Fig. 1).

\section{Chromoendoscopy and narrow band imaging (NBI)}

Chromoendoscopy with methylene blue, an absorptive dye, has been extensively studied, but largely has fallen out of favor due to lack of demonstration of superiority over protocoled biopsies and potential oxidative damage to cells $(41,42)$.

Acetic acid and non absorbed contrast stains like Indigo Carmine have shown to increase diagnostic yield for neoplasia when used in combination with magnification or HRE (43-48).

NBI is a virtual chromoendoscopy that uses a special filter to illuminate tissue with light at specific wavelengths, enhancing underlying vasculature and emphasizing contrast between vessels and their surrounding mucosa. Vascular patterns identified by magnified NBI have shown a good correlation with HGD and cancer on BE $(49,50)$ (Fig. 1).

Although some reports have shown superiority of NBI over WLE (51), it has not improved interobserver agreement or yield of detecting early neoplasia in BE when compared with HRE (39,52-54).

A recent international, randomized crossover trial showed NBI imaging with targeted biopsies to have the same detection rate of intestinal metaplasia as HRE-WLE and protocolized random biopsies, but with a higher proportion of dysplasia detected (30\%vs. $21 \%)$ and a lower number of biopsies per patient (3.6 vs. 7.6) (55).

NBI can be a helpful tool in guiding endoscopists to get targeted biopsies with no additional risks to the patient but it has yet to be been validated in large, randomized 

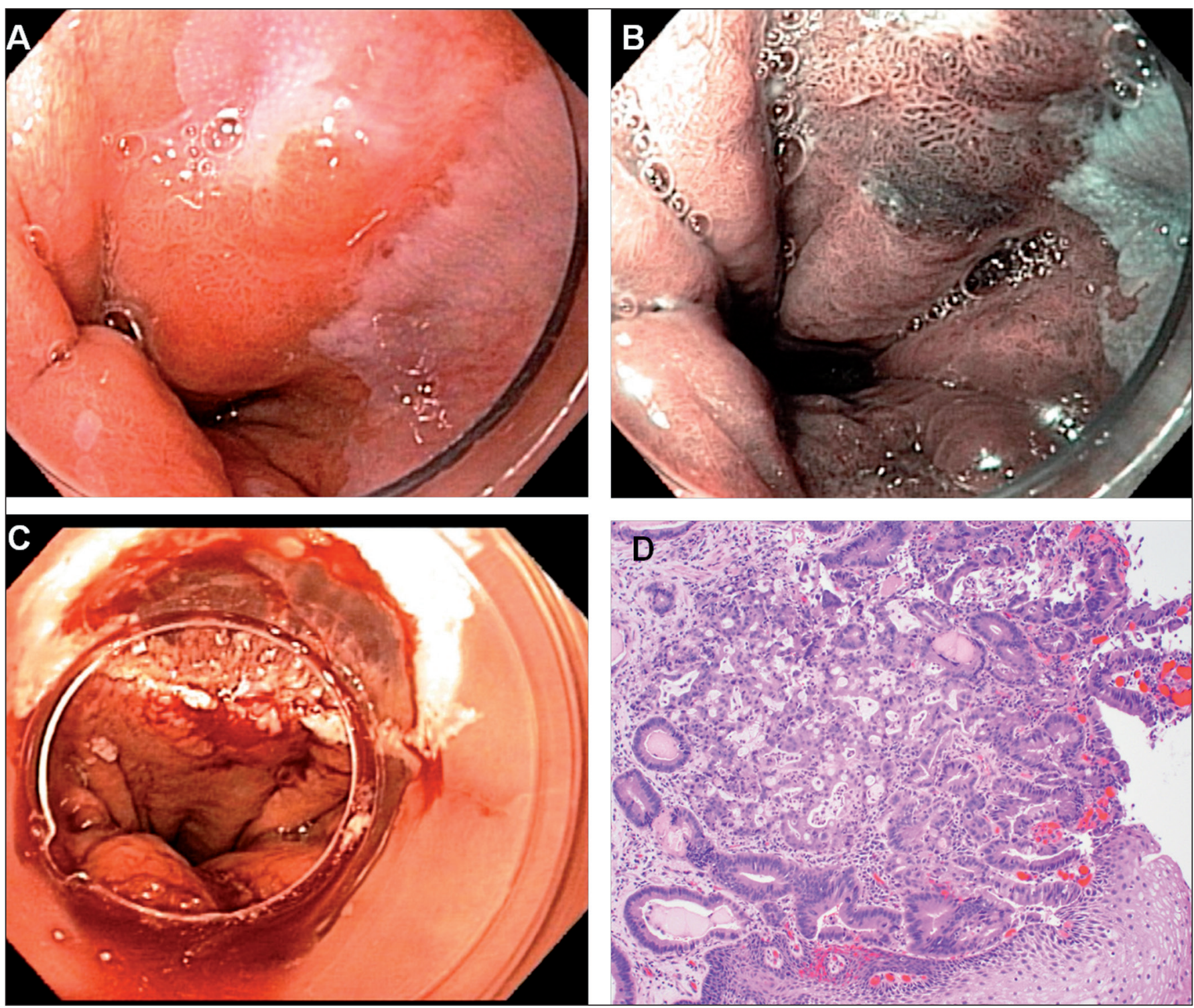

Fig. 1. A. Short segment Barrett esophagus (BE) with a slightly elevated lesion. B. Narrow band imaging (NBI) examination shows short segment BE with a 0-lla lesion showing an irregular pattern. C. Cap assisted endoscopic mucosal resection (EMR). D. Histopathology shows intramucosal carcinoma (IMC) arising from an area of high grade dysplasia (top right). Normal squamous mucosa is identified in the lower right corner.

multicenter trials before detailed inspection with NBI can replace histological sampling

\section{Confocal laser endomicroscopy (CLE)}

CLE allows in vivo functional imaging of Barrett mucosa by using topically or systemically administered contrast agents. Several studies have shown high accuracy rates when compared with standard examinations, with a substantial interobserver agreement (56-62). An international multicenter trial demonstrated that CLE significantly improved sensitivity for the detection of
HGD or cancer compared with HD-WLE with random and targeted biopsies alone $(34.2 \%$ vs. $68.3 \%)$ with no decrease in specificity (87.8\%) (63). Classification systems for Barrett's and dysplasia been described for endomicroscopy (56,64-66).

Disadvantages of CLE include additional procedural time and its elevated cost.

\section{Autofluorescence}

Autofluorescence imaging (AFI) is based on the excitation of endogenous molecules (fluorophores) 
by short wavelengths, resulting on the emission of fluorescent light Normal, metaplastic and dysplastic tissue have different autofluorescence spectra because of their different compositions of fluorophores (67).

While this technique has shown in studies a high sensitivity for the detection of HGD, specificity was poor with false positive rates up to $81 \%(38,68,69)$.

A multicenter study demonstrated a significant reduction of false positives when integrating NBI and AFI to a HRE in a trimodal prototype (70).

\section{Other techniques: Spectroscopy, optical coherence tomography (OCT)}

Spectroscopy is based on the study of the absorption, emission, or scattering of an incident light when applied to certain tissues (71). In vivo and ex vivo studies have shown the potential of spectroscopic information compared with neoplastic with non neoplasitic tissue in BE (72-74).

Optical coherence tomography can provide cross sectional images of tissue structure on the micron scale in situ and in real time by measuring back scattered or back reflected light (75). OCT has been studied for the diagnosis of NDBE and dysplasia in BE with promising results (76-78). OCT has also been described to reveal subepithelial glands in naive and in post-RFA Barrett's epithelium $(79,80)$.

According to current guidelines, there is lack of evidence for recommending the use of advanced imaging techniques for routine endoscopic evaluation of BE. All the advances in these technologies are bound to the ability of the endoscopist to understand subtle abnormalities and recognize concerning lesions. In expert hands, they can become a valuable tool in the detection of neoplasia and represent and incremental gain, not yet a substitute, for standard procedures.

\section{ENDOSCOPIC THERAPIES FOR BARRETT ESOPHAGUS}

Endoscopic ablative therapies can be divided into tissue-acquiring and non-tissue-acquiring methods. Tissueacquiring methods include endoscopic mucosal resection (EMR) and endoscopic submucosal dissection (ESD). Nontissue-acquiring methods include photodynamic therapy (PDT), radiofrequency ablation (RFA) and cryotherapy.

The rationale of these therapies resides in the risk of lymph node metastases when there is submucosal invasion.

High-grade dysplasia (HGD) is characterized by carcinoma in situ with malignant cells that do not invade the lamina propria. Intramucosal carcinoma (IMC), so called T1a by the AJCC (81), is defined as neoplastic changes confined to the lamina propria, with no invasion into the submucosal layer (82). In this stage, the risk of lymph node involvement is lower than $5 \%$ (83-86). On the other hand, submucosal involvement increases the risk of nodal metastases $(20 \%)$ and thus a surgical and/or systemic approach is required $(83,84,87,88)$.

Traditionally, patients with Barrett Esophagus and HGD underwent immediate esophagectomy because of the estimated risk that $40 \%$ of such patients harbored occult cancer $(89,90)$. In a meta-analysis of 23 studies involving 441 patients undergoing surgery for HGD, the pooled rate of adenocarcinoma was $39.9 \%$. However, the majority of these patients had IMC, whereas the rate of submucosal invasive cancer was decreased to $12.7 \%$ (91). Subsequent studies from the surgical and endoscopic resection literature have reported even lower rates, between $4 \%$ and $6.7 \%(92,93)$.

Based on a recent systematic review, the risk of lymph node metastasis is approximated to be 1-2 \% among patients with IMC and $0 \%$ among patients with HGD (86).

Endoscopic therapy has emerged in this context as a minimally invasive approach for treatment of HGD or IMC as an alternative to esophagectomy, which is associated with significant mortality and morbidity $(94,95)$.

\section{Tissue adquiring techniques}

Visible lesions in patients with dysplastic Barrett esophagus are associated with higher risk of invasive carcinoma $(85,96)$ and should be treated with a tissueacquiring modality so these lesions can be appropriately resected and staged histologically (97).

The updated Paris classification categorizes superficial lesions in esophagus into: Protruding pedunculated (type 0-Ip), protruding sessile (0-Is), slightly elevated (0-IIa), completely flat (0-IIb), slightly depressed (0IIc), excavated (0-III), or a mixed pattern (98). A Dutch retrospective study on 293 endoscopic resection specimens with correlation to endoscopic characteristics found that type 0-I and 0-IIc lesions significantly more often penetrated the submucosa $(\mathrm{p}=0.009)(99)$.

Standard endoscopic procedures for obtaining biopsy samples have several limitations, including limited tissue sample size and depth, and artifacts that result from compression of the specimen (100). Appropriate diagnosis and staging of visible lesions is, therefore, achieved by use of endoscopic mucosal resection (EMR) or endoscopic submucosal dissection (ESD) techniques that yield large and intact tissue specimens and can provide a more reliable diagnosis than is possible with standard procedures (101).

\section{Endoscopic mucosal resection (EMR)}

Endoscopic mucosal resection (EMR) permits an accurate evaluation of the depth and lateral resection 
margins and also provides information about the presence of submucosal involvement.

EMR specimens enhance the ability of pathologists to establish accurate diagnoses and stage tumors, compared with mucosal biopsies (Figs. 1 and 2). Furthermore, different studies have shown that staging by EMR can modify the previous biopsy diagnosis in up to $48 \%$ of cases $(93,102,103)$, which can dramatically change the clinical management of these patients, some of whom would be no longer suitable for endoscopic treatment due to histological evidence of submucosal invasion. Tumor staging using EMR pathology assessment is accurate when compared with surgical pathology, as shown in a study in 25 patients with HGD, IMC in Barrett's esophagus, where there was perfect agreement in T staging after EMR and esophagectomy (104).

Several techniques have been described for endoscopic resection of superficial lesions: Free-hand, lift-and-cut, cap-assisted, or band-assisted (105). These techniques have been shown to be equivalent in terms of safety, efficacy and the depth of the tissue specimen obtained $(100,106,107)$. The most commonly used are cap-assisted technique after submucosal lifting and the multiband ligation assisted technique (MBM), which is based on modification of the variceal ligation devices (108) (Figs. 1 and 2).

Focal EMR has shown to have a low profile of complications. Bleeding has been reported in $0.6-11 \%$ of cases (most of them minor episodes managed intraprocedure)
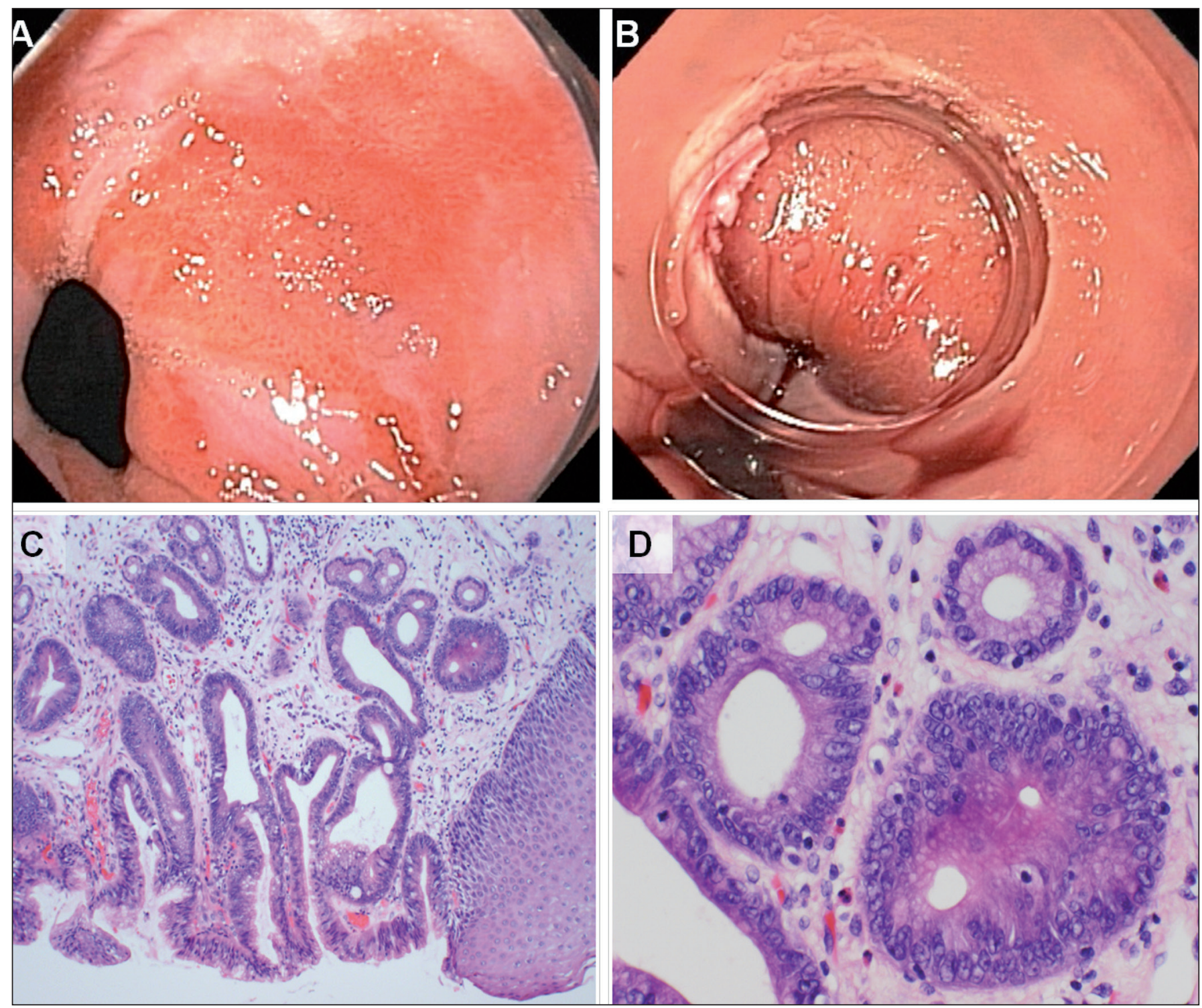

Fig. 2. A-B. Barrett esophagus cap assisted mucosectomy of an area of mucosal irregularity. C. Low power field demonstrates normal squamous mucosa (lower right corner) adjacent to an area of both low and high grade dysplasia (left). D. Examination at high power (40 X) reveals a few neoplastic glands displaying high grade morphology: High nuclei: Cytoplasm $(\mathrm{N}: \mathrm{C})$ ratio, loss of polarity and cribriforming architecture (right). 
and perforations in less of $2 \%$ of cases. Stricture formation for focal EMR is $<5 \%$ and increases significantly when longer segments of $\mathrm{BE}$ are resected and when used in combination with ablative techniques (109-113).

EMR can be performed focally for staging endoscopically visible lesions that are suspicious for malignancy, but focal resection has been associated with a high rate of synchronous, metachronous and recurrent lesions in the residual Barrett's mucosa, which can reach to more than $30 \%$ after a follow-up period of 3 years (92,111,114-116). Therefore, once that all areas of localized neoplasia have been removed and appropriately staged, the remainder of the Barrett epithelium, in which there is a well established presence of molecular abnormalities, should be eradicated $(5,117)$. Eradication of the "at risk" BE may be done by tissue acquiring or non-tissue acquiring means.

\section{Complete Barrett's eradication endoscopic mucosal resection (CBE-EMR)}

CBE-EMR, also known as circumferential endoscopic mucosal resection or stepwise radical endoscopic resection, involves resecting the entire Barrett's segment after a targeted ablation of visible lesions in patients with HGD or IMC. This minimizes the risk of potential development of synchronous or metachronous lesions (93) (Fig. 3).

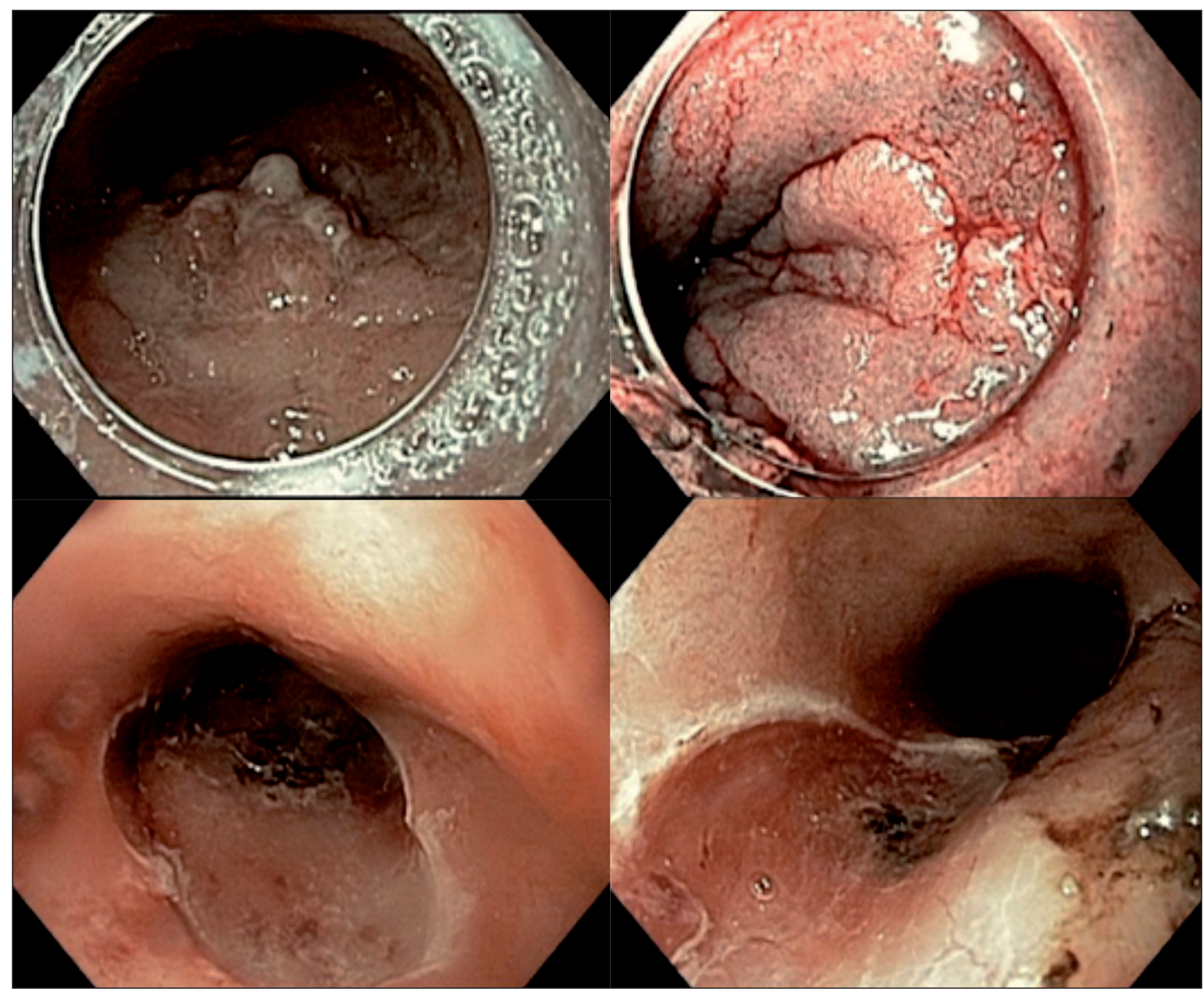

Fig. 3. Up. A $17 \mathrm{~cm}$ long Barrett's esophagus with a mixed 0-Ila+llc lesion (high resolution endoscopy $\{\mathrm{HRE}\}$ on the left, and narrow band imaging $\{\mathrm{NB} \mid\}$ on the right). Down. Endoscopic view after first session of complete Barrett's esophagus endoscopic mucosal resection (CBE-EMR) with a total of 17 resections. 
Complete response from CBE-EMR in studies has ranged from 76 to $100 \%$ and complete eradication of dysplasia in $86 \%$ to $100 \%$ of cases $(93,118-123)$ (Table II).

The major limitation for CBE-EMR is the high incidence of symptomatic stenosis, with rates reaching $50 \%$ in some reports. The length of BE resected segment and the number of EMR procedures performed were associated with higher rates of strictures $(92,93,124)$. Noteworthy, strictures caused by CBE-EMR respond favorably to endoscopic dilation.

When compared to other approaches that combine endoscopic resection with non-tissue acquiring modalities such as RFA, van Vilsteren et al. found similar rates of complete response of neoplasia $-100 \%$ for CBE-EMR $v s$. $96 \%$ for endoscopic resection plus RFA (ER/RFA)- and complete remission of intestinal metaplasia ( $92 \%$ vs. $96 \%$ ). The stenosis rate was significantly higher in CBE-EMR (88 \% vs. $14 \% ; \mathrm{p}<0.001)$, resulting in more therapeutic sessions ( 6 vs. $3 ; \mathrm{p}<0.001)$ due to dilations (123).

CBE-EMR has some potential advantages when compared with non tissue acquiring ablative therapies. It allows complete removal of the whole mucosa at risk for malignant progression, though providing tissue samples for optimal histopathology diagnosis. It may also reduce the risk of buried glands of Barrett's mucosa underneath the neosquamous epithelium mucosa compared with ablative therapies, and finally It may reduce the likelihood of persistent and/or induced genetic abnormalities that are associated with the progression of $\mathrm{BE}$ to adenocarcinoma, as there is recent concern that ablation may select for certain clonal populations (125). CBE-EMR may be optimal for patients with multifocal disease, diffuse nodularity, deep Barrett's glands or other high-risk markers that have yet to be elucidated.

\section{Endoscopic submucosal dissection (ESD)}

ESD has been widely used for treating gastrointestinal neoplasms in Japan. With this approach, en-bloc resection can be done regardless of the size of the lesion. It is considered the treatment of choice for intramucosal gastric cancer and it has shown excellent results in esophageal and colon cancer, superior to conventional EMR in terms of curative resection and recurrence rates (126-128).

ESD has shown excellent curative rates in squamous cell cancer and, as BE incidence is much lower than in western countries, most of the reports on BE are limited to adenocarcinomas of the esophagogastric junction (129132). The advantages of ESD over EMR might be not as clear for lesions smaller than $15 \mathrm{~mm}(133,134)$.

Given the excellent long term outcomes of EMR, advantages of ESD compared to conventional EMR could be less relevant in treatment of early Barrett's neoplasia. ESD is a technically demanding procedure, time consuming and is associated with a higher rate of adverse events $(128,132)$. A high level of endoscopic expertise and a minimum training requirement are recommended for its safe application (135-137).

The role of ESD in the therapeutic algorithm for Barrett's esophagus in Western countries is still not established, and so far experience in Europe and USA is limited $(136,138)$.

\section{Cost effectiveness}

A recent decision analysis suggest that endoscopic therapy (diagnostic EMR combined with RFA to achieve complete ablation of $\mathrm{BE}$ ) is more cost-effective than esophagectomy for IMC but also with superficial infiltration of the submucosa. According to this, endoscopic therapy may be best suited for patients with an a priori high surgical risk, such as the elderly or patients with comorbid illnesses, in whom perioperative mortality and postoperative morbidity outweigh the lower risk of recurrence after surgery compared with endoscopic therapy (139).

Table II. Overview of studies reporting endoscopic mucosal resection (EMR) for complete removal of BE

\begin{tabular}{|c|c|c|c|c|c|c|c|c|c|}
\hline Author & $n$ & $\begin{array}{l}\text { Follow up } \\
\text { (months) }\end{array}$ & $\begin{array}{c}\text { EMR } \\
\text { sessions } \\
\text { (median) }\end{array}$ & $\begin{array}{l}\text { Complete } \\
\text { regression of } \\
\text { IM (\%) }\end{array}$ & $\begin{array}{l}\text { Complete } \\
\text { regression of } \\
\text { dysplasia (\%) }\end{array}$ & $\begin{array}{l}\text { Recurrence } \\
\text { (\%) }\end{array}$ & $\begin{array}{l}\text { Progression } \\
(\%)\end{array}$ & $\begin{array}{l}\text { Strictures } \\
(\%)\end{array}$ & $\begin{array}{l}\text { Other major } \\
\text { complications }\end{array}$ \\
\hline Peters 2006 (118) & 32 & 11 & 3 & 89 & 100 & 0 & 0 & 26 & 5 \\
\hline Lopes 2007 (119) & 41 & 32 & 1.5 & 75.6 & 100 & 36 & 0 & 5 & 9.5 \\
\hline Larghi 2007 (120) & 24 & 28 & 3 & 87 & 100 & 4 & 0 & 12.5 & 0 \\
\hline Chennat 2009 (93) & 49 & 17 & 2.1 & 97 & 100 & 0 & 0 & 37 & 0 \\
\hline Pouw 2010 (121) & 169 & 32 & 2 & 97.6 & 85.2 & 1.8 & 0.6 & 49.7 & 1.2 \\
\hline Gerke 2011 (122) & 46 & 25 & 2.4 & 78 & 85.4 & 4 & 0 & 43.9 & 4.9 \\
\hline $\begin{array}{l}\text { van Vilsteren } 2011 \\
\text { (123) }\end{array}$ & 25 & 24 & 2 & 92 & 100 & 4 & 0 & 88 & 24 \\
\hline
\end{tabular}




\section{The role of EUS in Barrett esophagus}

Endoscopic ultrasonography (EUS) is considered the most accurate imaging modality for the $\mathrm{T}$ staging of gastrointestinal cancers, but the role of EUS has limited value in the pre-therapeutic algorithm of patients with early Barrett's neoplasia (140).

EUS is not optimal for differentiation between HGD, a T1a tumor (IMC) and a T1b (SMC) tumor, and EMR is better suited for depth staging at this range $(141,142)$. High frequency probes have also shown to have a limited accuracy for identifying invasive cancer in HGD/IMC patients (143). These limitations of EUS for an accurate diagnosis of early Barrett's cancer seem to be higher in flat and depressed lesions (141).

However, given the risk of lymph node metastasis in patients with visible lesions or confirmed superficial submucosal invasion, EUS with fine needle aspiration (FNA) might identify patients not eligible for endoscopic therapy (142).

\section{Non tissue adquiring techniques}

As aforementioned the rationale for ablative methods for $\mathrm{BE}$ is the well established presence of molecular abnormalities in the remaining Barrett's epithelium after focal resection of neoplastic lesions and the risk for developing metachronous or synchronous lesions, making the eradication of the entire Barrett's segment essential. When no visible lesion is macroscopically detected after a carefully examination with HRE, ablative methods may be the first of choice therapy for HGD.

\section{Radiofrequency ablation (RFA)}

This technique uses an electrode to deliver high frequency energy to the superficial lining of the esophagus over a very short period of time. RFA of BE tissue can be achieved in either a circumferential (BARRX-Halo 360 ) or localized fashion for focal areas of residual Barrett's epithelium (BARXX Halo 90º) (144) (Fig. 4).

The available data from prospective trials are summarized in Table III (123,145-156).

\section{Efficacy}

In a multicenter randomized, sham-controlled trial on 127 patients with dysplastic BE complete eradication of dysplasia was achieved in $91 \%$ and $81 \%$ of patients with LGD and HGD in the RFA group, respectively, compared with $3 \%$ (LGD) and $19 \%$ (HGD) in the control group $(\mathrm{p}<0.001)$ after one year $(150)$. After 3 years, dysplasia remained eradicated in $>85 \%$ of patients and IM in $>75 \%$, without maintenance RFA (151).

In the AIM II trial, which included patients with NDBE, complete eradication of IM was achieved in $98.4 \%$ and $92 \%$ at 2.5 and 5 year follow up, respectively (152).

In a recent meta-analysis of 20 studies comprising more than 4,000 patients, complete eradication of dysplasia was achieved in $91 \%$ and eradication of all IM in $78 \%$ of patients with a rate of esophageal strictures of $5 \%$ of patients (157).

EMR appears to be safe to perform prior or posterior to RFA. Stricture rates among patients who receive only RFA are comparable to those of patients who had prior subsequent EMR for residual lesions $(149,158,159)$.

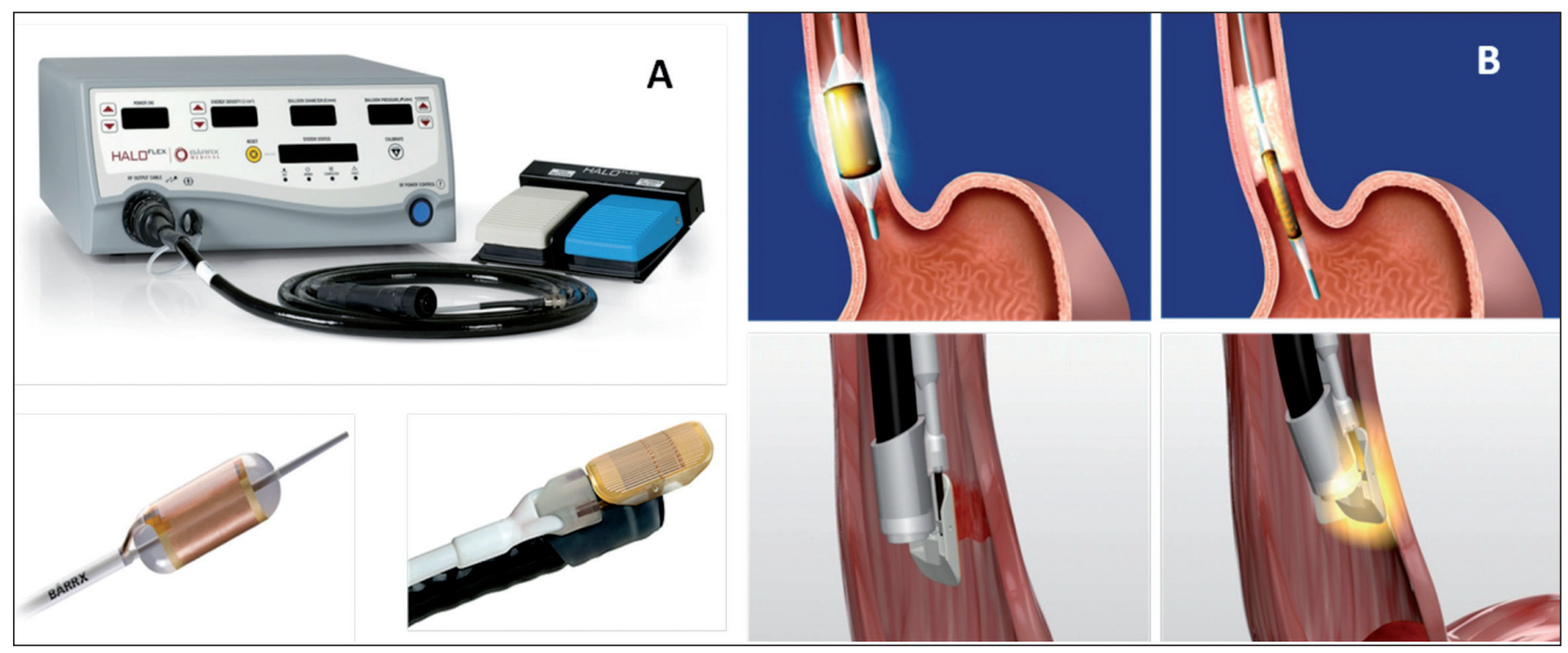

Fig. 4. HALO FLEXTM generator for radiofrequency ablation. HALO 360 and HALO 90 ablation catheters. B. Diagram showing circumferential RFA (up) and focal RFA (down) (Under permission of Izasa, sales representative of BARXX for Spain). 
Table III. Overview of main studies reporting radiofrequency ablation (RFA) for Barrett's esophagus

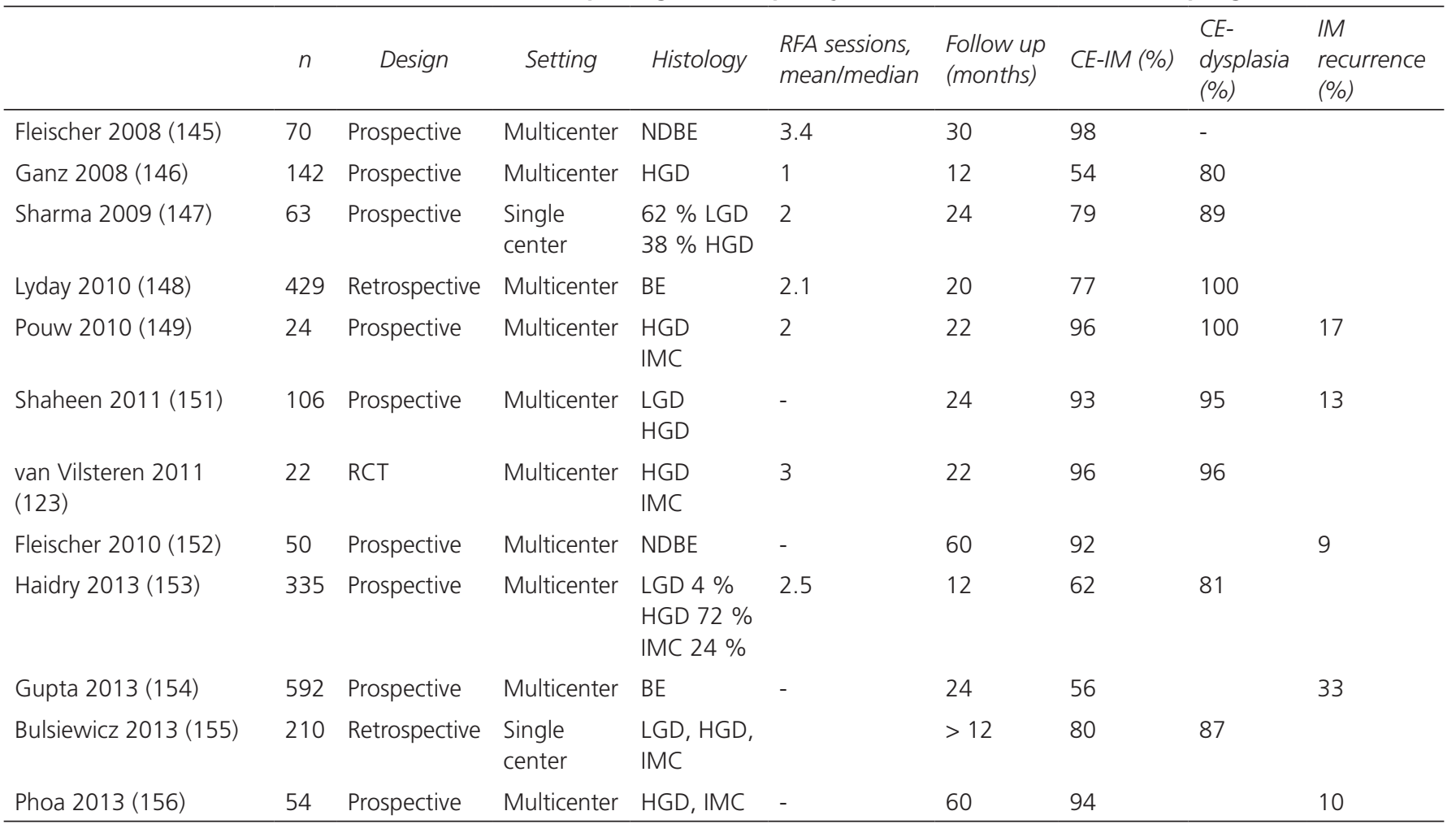

CE-IM: Complete eradication of intestinal metaplasia; NDBE: Non dysplastic Barrett esophagus; LGD: Low grade dysplasia; HGD: High grade dysplasia; BE: Non dysplastic and dysplastic Barrett esophagus; RCT: Randomized controlled trial; IMC: Intramucosal carcinoma.

A poor initial response to RFA occurs more frequently in patients who regenerate their endoscopic resection scar with Barrett's epithelium, those with ongoing reflux esophagitis, neoplasia in BE for a longer time, or a narrow esophagus (156). Persistent total reflux, hiatal hernia and its size and the length of $\mathrm{BE}$ have been associated with the need for more RFA sessions $(160,161)$.

\section{Durability}

Although RFA safely and effectively eradicates dysplasia and IM, the durability of the neosquamous epithelium that regenerates is not well defined.

Recently, three multicenter studies, from 3 different populations were published providing data of long term outcomes of patients treated with RFA $(153,154,156)$. In the Dutch population study, among 54 patients with HGD or IMC who underwent RFA, $90 \%$ remain in remission at 5-year follow-up, with all recurrences managed endoscopically (156). In the UK study, among 335 patients with BE and neoplasia who underwent RFA, dysplasia was cleared from $81 \%$ and BE from $62 \%$ of patients 12 months after treatment (153). In the multicenter US study, from 592 patients with BE (71\% HGD or EAC) treated by RFA, $56 \%$ were in complete remission after 24 months. However, $33 \%$ of these patients had disease recurrence within the next 2 years. Most recurrences were nondysplastic and endoscopically manageable (154). Noteworthy, IM of the cardia was considered recurrence in the US study. Technique of ablation and acid suppression were also different between the three studies.

These data suggest that a large proportion of patients will have durable eradication of their dysplasia but there is a persistent risk of recurrent metaplasia and dysplasia. This emphasizes the importance of careful endoscopic surveillance after successful ablation with RFA.

\section{Cost effectiveness}

Recent analysis have shown that RFA is unlikely to be cost effective for patients with BE without dysplasia (162).

RFA might be cost effective for confirmed and stable LGD, but it depends on the long-term effectiveness of ablation and whether surveillance endoscopy can be discontinued after successful ablation (163).

There is high agreement that endoscopic therapy is the preferred strategy for managing patients with $\mathrm{BE}$ with HGD. 
In the aforementioned decision analysis study initial RFA in HGD is more effective and less costly than endoscopic surveillance or surgery (162). Although endoscopic surveillance might be less expensive than endoscopic ablation, it is associated with shorter survival (164).

\section{RFA for non dysplastic Barrett esophagus and low grade dysplasia $B E$}

Although the low rates of recurrence of intestinal metaplasia (IM) after RFA have been published on patients with NDBE (152) these patients already have a low baseline risk for developing neoplasia, even lower than previously thought, societies like the AGA recommend against endoscopic eradication therapy for the general population of NDBE patients.

Whether RFA should be performed in the setting of low-grade dysplasia might be one of the most controversial debates in this field. As aforementioned, the risk of progression is poorly understood, and this risk could be much higher when diagnosis is confirmed by a second pathologist (30). Recurrence rates of RFA and significance of buried glands are yet to be defined, and currently endoscopic surveillance cannot be discontinued after eradication therapies.

A better understanding of ablative therapies, improvement on endoscopic detection of dysplasia and the urgency of identifying patients with a higher risk of progression to cancer probably by using biological markers are awaited to clarify current recommendations.

\section{Photodynamic therapy (PDT)}

Photodynamic therapy is based on the formation of oxygen radicals and subsequent cell death when light of an appropriate wavelength is delivered to a tissue previously exposed to a photosensitizing agent. The most widely used agent for esophageal PDT is porfimer sodium (Ps), 5-aminolevulinic acid (5-ALA) which can be administered orally, has been used in Europe. Light is delivered to the tissue via an endoscopic approach.

A multicenter randomized trial by Overholt et al. (165) showed at 5 years follow up that PDT plus omeprazole was significantly more effective than omeprazole alone in eliminating HGD (77 \% vs. $39 \%$ ). Progression to cancer was also significantly lower in the PDT group (15\% vs. $29 \%$ ). There is less evidence with other photosensitizers such as ALA; a study by Pech et al. showed a complete response in $97 \%$ of HGD patients and in $100 \%$ of IMC patients treated with ALA-PDT after a median follow-up period of 37 months (166).

PDT was comparable to surgery in terms of surgical mortality and long-term survival in a retrospective study after a mean follow-up period of approximately 5 years (104) PDT also showed to be cost effective when compared with esophagectomy in patients with HGD (167).

The major drawback of PDT is the relatively high rate of reported adverse events, mainly photosensitivity and symptomatic strictures, which have been reported in up to $36 \%$ of patients (97). Another concern about PDT is development of sub-squamous BE glands that could harbor neoplastic potential, which was found to be $14 \%$ in a systematic review (168). In one study that examined histological and pathological specimens after PDT, buried glands were found in $51 \%$ of patients; $27 \%$ of these harbored dysplasia or carcinoma (169).

Given these limitations, PDT has fallen out of favour in recent years, and referral centers have adopted EMR and RFA as the preferred endoscopic treatment modalities for BE.

\section{Cryotherapy}

Cryotherapy is based on spraying the targeted tissues with cycles of either liquid nitrogen or rapidly expanding carbon dioxide gas, causing rapid freezing and slow thawing that destroy tissues through immediate and delayed effects (170).

Short term studies have shown a safety and efficacy profile similar to other ablative techniques (171-173). In a single center study with 32 patients, complete eradication (CE) of HGD was $100 \%$, and CE of IM was $84 \%$ at 2-year follow-up. At last follow-up (range 24-57 months), CE-HGD was $97 \%$ and CE-IM was $81 \%$. No serious adverse events occurred. Stricture was seen in 3 patients (9\%) (174). Multi-center randomized trials are required to confirm these results and determine long-term response. The optimal treatment protocol and direct comparative data with RFA will be needed before the role of cryotherapy is defined among ablative techniques for $\mathrm{BE}$.

\section{Other ablative therapies}

Argon plasma coagulation (APC) has been studied for ablation principally on NDBE (175-177). Given the high relapse rates observed, the concern regarding buried glands and a low benefit risk in this patients, APC is no longer used as ablation treatment, and is reserved as a "touch up" therapy to treat areas of IM left behind by other ablative modalities. Other techniques like multipolar electrocoagulation and laser therapies have also been replaced by other ablation modalities.

\section{The concern of buried glands}

A concern with regard to endoscopic ablation is the development of buried glands under the neosquamous 
epithelium. When the ablation procedure does not destroy all of the metaplastic epithelium, then the partially ablated mucosa may heal with an overlying layer of neosquamous epithelium that buries metaplastic glands in the lamina propria, becoming undetectable to endoscopic surveillance.

The significance of buried glands is unknown, and whether they might be present or not before ablation, but the development of adenocarcinoma under squamous epithelium has been reported $(140,178)$. A recent systematic review evaluated the evidence of buried metaplasia before and after ablation therapies. The baseline prevalences ranged from $0 \%$ to $28 \%$, in patients after PDT $14.2 \%$; and after RFA in only $0.9 \%$ (168).

But the true incidence and risk of progression to neoplasia might be underestimated. Besides the inherent sampling error from biopsy protocols, it is unclear whether the size and depth of biopsy specimens may be insufficient to identify buried glands $(179,180)$.

A recent study using tridimensional optical coherence tomography (3D-OCT) found buried glands in $72 \%$ of patients (13/18) before and in $63 \%$ of patients $(10 / 16)$ after complete eradication of intestinal metaplasia with RFA therapy (79).

Further studies are needed to resolve this issue.

\section{Combined endoscopic techniques}

The balance of tissue acquisition and adverse effect profile for patients with dysplasia may be best achieved with a hybrid approach where EMR is used for all visible lesions and the remainder of the epithelium is treated with serial RFA which carries a more favorable complication profile $(123,149,181,182)$.

\section{ESOPHAGECTOMY}

As discussed above, endoscopic treatment is an appropriate and cost-effective approach for the treatment of many patients with HGD and IMC, but a surgical approach is still indicated in a subgroup of these patients.

Strong indications for esophagectomy include lymph node metastasis and failure of endoscopic therapy. Submucosal invasion carries a higher nodal metastasis risk and can still be considered a strong indication for esophagectomy. Although some investigators have reported that the upper third of the submucosa $(\mathrm{sm} 1)$ has a very low risk of lymph node metastasis $(110,166,183,184)$, further clinical trials are required before a general recommendation for endoscopic treatment in "low-risk" submucosal cancer can be given (185).

Selected patients with HGD or IMC and high risk features should be also considered for surgical therapy. These high risk features include multifocal HGD, protruding or depressed lesions, poorly differentiated tumors, and invasion into lymphatic channels, blood vessels, or neural structures (186).

The main concern for esophagectomy is that it is associated with significant mortality and morbidity, with estimates of mortality ranging from $0 \%-2 \%$ at highvolume centers to $8 \%-10 \%$ at low volume centers (187). Increasing surgeon experience may similarly favorably impact operative mortality (188-191).

\section{CONCLUSIONS}

The advent of endoscopic ablative therapies has rapidly changed the management of Barrett esophagus. High grade dysplasia and intramucosal carcinoma are amenable for endoscopic treatment given the low risk of lymphatic spread in these stages, which increases substantially when submucosal invasion is present. Development in endoscopic diagnosis are meant to improve significantly the detection of dysplasia in the setting of $\mathrm{BE}$, as a complement or potentially instead of random biopsies. Endoscopically visible lesions in the setting of dysplasia should be targeted with focal endoscopic mucosal resection for accurate histopathologic diagnosis and treatment. The remainder of the Barrett's epithelium should also be eradicated to address all synchronous and metachronous lesions, for which serial RFA currently carries a more favorable complication profile.

Further investigations with endoscopic ablative therapies are needed to characterize rates of clinical remission of neoplasia and Barrett esophagus, long-term survival, risk of progression to cancer, and procedurerelated complications of the different modalities.

The significance of buried glands and their potential to harbor dysplasia or even cancer under squamous epithelium has yet to be elucidated. The role of ablative therapies for the treatment of low grade dysplasia and nondysplastic are yet to be defined. As long as the real risk of progression of low grade dysplasia remains unknown and the aforementioned questions regarding ablative therapies remain unanswered, endoscopic surveillance is recommended in these settings.

Although surgery is still an indication in selected cases, esophagus-sparing approaches will evidently become the mainstay of therapy for patients with high-grade dysplasia, intramucosal carcinoma and perhaps in case of superficial submucosal invasion.

\section{REFERENCES}

1. Pohl H, Welch HG. The role of overdiagnosis and reclassification in the marked increase of esophageal adenocarcinoma incidence. J Natl Cancer Inst 2005;97:142-6.

2. Solaymani-Dodaran M, Logan RF, West J, Card T, Coupland C. Risk of oesophageal cancer in Barrett's oesophagus and gastro-oesophageal reflux. Gut 2004;53:1070-4. 
3. Spechler SJ, Sharma P, Souza RF, Inadomi JM, Shaheen NJ. American Gastroenterological Association technical review on the management of Barrett's esophagus. Gastroenterology 2011;140:e18-52; quiz e13.

4. Shaheen NJ, Crosby MA, Bozymski EM, Sandler RS. Is there publication bias in the reporting of cancer risk in Barrett's esophagus? Gastroenterology 2000;119:333-8.

5. Bennett C, Vakil N, Bergman J, Harrison R, Idze R, Vieth M, et al. Consensus statements for management of Barrett's dysplasia and earlystage esophageal adenocarcinoma, based on a Delphi process. Gastroenterology 2012;143:336-46.

6. Gatenby PA, Ramus JR, Caygill CP, Shepherd NA, Watson A. Relevance of the detection of intestinal metaplasia in non-dysplastic columnar-lined oesophagus. Scand J Gastroenterol 2008;43:524-30.

7. Takubo K, Aida J, Naomoto Y, Sawabe M, Arai T, Shiraishi H, et al. Cardiac rather than intestinal-type background in endoscopic resection specimens of minute Barrett adenocarcinoma. Hum Pathol 2009;40:65-74.

8. Bhat S, Coleman HG, Yousef F, Johnston BT, McManus DT, Gavin AT, Murray LJ. Risk of malignant progression in Barrett's esophagus patients: Results from a large population-based study. J Natl Cancer Inst 2011;103:1049-57.

9. Desai TK, Krishnan K, Samala N, Subgh J, Clulev J, Perla S, et al. The incidence of oesophageal adenocarcinoma in non-dysplastic Barrett's oesophagus: A meta-analysis. Gut 2012;61:970-6.

10. Oh DS, Demeester SR. Pathophysiology and treatment of Barrett's esophagus. World J Gastroenterol 2010;16:3762-72.

11. Montgomery E, Bronner MP, Goldblum JR, Greenson JK, Haber MM, Hart J, et al. Reproducibility of the diagnosis of dysplasia in Barrett esophagus: A reaffirmation. Hum Pathol 2001;32:368-78.

12. Reid BJ, Haggitt RC, Rubin CE, Roth G, Surawicz CM, Van Belle $\mathrm{G}$, et al. Observer variation in the diagnosis of dysplasia in Barrett's esophagus. Hum Pathol 1988;19(2):166-78.

13. Downs-Kelly E, Mendelin JE, Bennett AE, Castilla E, Henricks WH, Schoenfield L, et al. Poor interobserver agreement in the distinction of high-grade dysplasia and adenocarcinoma in pretreatment Barrett's esophagus biopsies. Am J Gastroenterol 2008;103:2333-40.

14. Peters JH, Clark GW, Ireland AP, Chandrasoma P, Smyrk TC, DeMeester TR. Outcome of adenocarcinoma arising in Barrett's esophagus in endoscopically surveyed and nonsurveyed patients. J Thorac Cardiovasc Surg 1994;108:813-21; discussion 21-2.

15. Fountoulakis A, Zafirellis KD, Dolan K, Dexter SP, Martin IG, SueLing HM. Effect of surveillance of Barrett's oesophagus on the clinical outcome of oesophageal cancer. Br J Surg 2004;91:997-1003.

16. Ferguson MK, Durkin A. Long-term survival after esophagectomy for Barrett's adenocarcinoma in endoscopically surveyed and nonsurveyed patients. J Gastrointest Surg 2002;6:29-35; discussion 6.

17. Wang KK, Sampliner RE. Updated guidelines 2008 for the diagnosis, surveillance and therapy of Barrett's esophagus. Am J Gastroenterol 2008:103:788-97.

18. Spechler SJ, Sharma P, Souza RF, Inadomi JM, Shaheen NJ. American Gastroenterological Association medical position statement on the management of Barrett's esophagus. Gastroenterology 2011;140:108491.

19. Evans JA, Early DS, Fukami N, Ben-Menachem T, Chandrasekhara V, Chathadi KV, et al. The role of endoscopy in Barrett's esophagus and other premalignant conditions of the esophagus. Gastrointest Endosc 2012;76:1087-94.

20. Fitzgerald RC, di Pietro M, Ragunath K, Ang Y, Kang JY, Watson P, et al. British Society of Gastroenterology guidelines on the diagnosis and management of Barrett's oesophagus. Gut 2014;63:7-42.

21. Hvid-Jensen F, Pedersen L, Drewes AM, Sorensen HT, Funch-Jensen P. Incidence of adenocarcinoma among patients with Barrett's esophagus. N Engl J Med 2011;365:1375-83.

22. Gaddam S, Singh M, Balasubramanian G, Thota P, Gupta N, Wani S, et al. Persistence of nondysplastic Barrett's esophagus identifies patients at lower risk for esophageal adenocarcinoma: Results from a large multicenter cohort. Gastroenterology 2013;145:548-53 e1.

23. Corley DA, Mehtani K, Quesenberry C, Zhao W, de Boer J, Weiss NS. Impact of endoscopic surveillance on mortality from Barrett's esophagus-associated esophageal adenocarcinomas. Gastroenterology 2013;145:312-9 e1.

24. Sikkema M, de Jonge PJ, Steyerberg EW, Kuipers EJ. Risk of esophageal adenocarcinoma and mortality in patients with Barrett's esopha- gus: A systematic review and meta-analysis. Clin Gastroenterol Hepatol 2010;8:235-44; quiz e32.

25. Gordon LG, Mayne GC, Hirst NG, Bright T, Whiteman DC, Watson DI. Cost-effectiveness of endoscopic surveillance of non-dysplastic Barrett's esophagus. Gastrointest Endosc 2014;79:242-56.

26. Das A, Wells C, Kim HJ, Fleischer DE, Crowell MD, Sharma VK. An economic analysis of endoscopic ablative therapy for management of nondysplastic Barrett's esophagus. Endoscopy 2009;41:400-8.

27. Vaezi MF, Kahrilas PJ. Barrett's esophagus surveillance: Time to rethink if one size fits all? Gastroenterology 2013;145:503-5.

28. Conio M, Blanchi S, Lapertosa G, Ferraris R, Sablich R, Marchi S, et al. Long-term endoscopic surveillance of patients with Barrett's esophagus. Incidence of dysplasia and adenocarcinoma: A prospective study. Am J Gastroenterol 2003;98:1931-9.

29. Wani S, Falk GW, Post J, Yerian L, Hall M, Wang A, et al. Risk factors for progression of low-grade dysplasia in patients with Barrett's esophagus. Gastroenterology 2011;141:1179-86, $86 \mathrm{e} 1$.

30. Curvers WL, ten Kate FJ, Krishnadath KK, Visser M, Elzer B, Baak LC, et al. Low-grade dysplasia in Barrett's esophagus: Overdiagnosed and underestimated. Am J Gastroenterol 2010;105:1523-30.

31. Rastogi A, Puli S, El-Serag HB, Bansal A, Wani S, Sharma P. Incidence of esophageal adenocarcinoma in patients with Barrett's esophagus and high-grade dysplasia: A meta-analysis. Gastrointest Endosc 2008;67:394-8

32. Levine DS, Haggitt RC, Blount PL, Rabinovitch PS, Rusch VW, Reid BJ. An endoscopic biopsy protocol can differentiate high-grade dysplasia from early adenocarcinoma in Barrett's esophagus. Gastroenterology 1993;105:40-50.

33. Fitzgerald RC, Saeed IT, Khoo D, Farthing MJ, Burnham WR. Rigorous surveillance protocol increases detection of curable cancers associated with Barrett's esophagus. Dig Dis Sci 2001;46:1892-8.

34. Abela JE, Going JJ, Mackenzie JF, McKernan M, O'Mahoney S, Stuart RC. Systematic four-quadrant biopsy detects Barrett's dysplasia in more patients than nonsystematic biopsy. Am J Gastroenterol 2008;103:850-5.

35. Abrams JA, Kapel RC, Lindberg GM, Saboorian MH, Genta RM, Neugut AI, et al. Adherence to biopsy guidelines for Barrett's esophagus surveillance in the community setting in the United States. Clin Gastroenterol Hepatol 2009; 7:736-42; quiz 10.

36. Das D, Ishaq S, Harrison R, Kosuri K, Haroer E, Decaestecker J, et al. Management of Barrett's esophagus in the UK: Overtreated and underbiopsied but improved by the introduction of a national randomized trial. Am J Gastroenterol 2008;103:1079-89.

37. Curvers WL, Peters FP, Elzer B, Schaap AJ, Baak LC, van Olien A, et al. Quality of Barrett's surveillance in The Netherlands: a standardized review of endoscopy and pathology reports. Eur J Gastroenterol Hepatol 2008;20:601-7.

38. Kara MA, Smits ME, Rosmolen WD, Bultje AC, Ten Kate FJ, Fockens $\mathrm{P}$, et al. A randomized crossover study comparing light-induced fluorescence endoscopy with standard videoendoscopy for the detection of early neoplasia in Barrett's esophagus. Gastrointest Endosc 2005;61:671-8.

39. Kara MA, Peters FP, Rosmolen WD, Krishnadath KK, ten Kate FJ, Fockens P, et al. High-resolution endoscopy plus chromoendoscopy or narrow-band imaging in Barrett's esophagus: A prospective randomized crossover study. Endoscopy 2005;37:929-36.

40. Guelrud M, Herrera I, Essenfeld H, Castro J. Enhanced magnification endoscopy: A new technique to identify specialized intestinal metaplasia in Barrett's esophagus. Gastrointest Endosc 2001:53:559-65.

41. Olliver JR, Wild CP, Sahay P, Dexter S, Hardie LJ. Chromoendoscopy with methylene blue and associated DNA damage in Barrett's oesophagus. Lancet 2003;362:373-4.

42. Ngamruengphong S, Sharma VK, Das A. Diagnostic yield of methylene blue chromoendoscopy for detecting specialized intestinal metaplasia and dysplasia in Barrett's esophagus: A meta-analysis. Gastrointest Endosc 2009;69:1021-8.

43. Bruno MJ. Magnification endoscopy, high resolution endoscopy, and chromoscopy; towards a better optical diagnosis. Gut 2003;52(Supl. 4):iv7-11.

44. Costello S, Singh R. Endoscopic Imaging in Barrett's oesophagus: Applications in routine clinical practice and future outlook. Clin Endosc 2011;44:87-92. 
45. Longcroft-Wheaton G, Duku M, Mead R, Poller D, Bhandari P. Acetic acid spray is an effective tool for the endoscopic detection of neoplasia in patients with Barrett's esophagus. Clin Gastroenterol Hepatol 2010;8:843-7.

46. Pohl J, May A, Rabenstein T, Pech O, Nguyen-Tat M, Fissler-Eckhoff A, et al. Comparison of computed virtual chromoendoscopy and conventional chromoendoscopy with acetic acid for detection of neoplasia in Barrett's esophagus. Endoscopy 2007;39:594-8.

47. Sharma P, Marcon N, Wani S, Bansal A, Mathur S, Sampliner R, et al. Non-biopsy detection of intestinal metaplasia and dysplasia in Barrett's esophagus: A prospective multicenter study. Endoscopy 2006;38:120612.

48. Pohl J, Pech O, May A, Manner H, Fissler-Eckhoff A, Ell C. Incidence of macroscopically occult neoplasias in Barrett's esophagus: Are random biopsies dispensable in the era of advanced endoscopic imaging? Am J Gastroenterol 2010;105:2350-6.

49. Sharma P, Bansal A, Mathur S, Wani S, Cherian R, McGregor D, et al. The utility of a novel narrow band imaging endoscopy system in patients with Barrett's esophagus. Gastrointest Endosc 2006;64:167-75.

50. Curvers WL, van den Broek FJ, Reitsma JB, Dekker E, Bergman JJ. Systematic review of narrow-band imaging for the detection and differentiation of abnormalities in the esophagus and stomach (with video). Gastrointest Endosc 2009;69:307-17.

51. Wolfsen HC, Crook JE, Krishna M, Achem SR, Devault KR, Bouras EP, et al. Prospective, controlled tandem endoscopy study of narrow band imaging for dysplasia detection in Barrett's Esophagus. Gastroenterology 2008;135:24-31.

52. Curvers W, Baak L, Kiesslich R, Van Oijen A, Rabenstein T, Raqunath $\mathrm{K}$, et al. Chromoendoscopy and narrow-band imaging compared with high-resolution magnification endoscopy in Barrett's esophagus. Gastroenterology 2008;134:670-9.

53. Curvers WL, Bohmer CJ, Mallant-Hent RC, Naber AH, Ponsioen CI, Ragunath K, et al. Mucosal morphology in Barrett's esophagus: Interobserver agreement and role of narrow band imaging. Endoscopy 2008;40:799-805.

54. Herrero LA, Curvers WL, Bansal A, Wani S, Kara M, Schenk E, et al. Zooming in on Barrett oesophagus using narrow-band imaging: An international observer agreement study. Eur J Gastroenterol Hepatol 2009:21:1068-75.

55. Sharma P, Hawes RH, Bansal A, Gupta N, Curvers W, Rastogi A, et al. Standard endoscopy with random biopsies versus narrow band imaging targeted biopsies in Barrett's oesophagus: A prospective, international, randomised controlled trial. Gut 2013;62:15-21.

56. Kiesslich R, Gossner L, Goetz M, Dahlmann A, Vieth M, Stolte M, et al. In vivo histology of Barrett's esophagus and associated neoplasia by confocal laser endomicroscopy. Clin Gastroenterol Hepatol 2006;4:979-87.

57. Dunbar KB, Canto MI. Confocal laser endomicroscopy in Barrett's esophagus and endoscopically inapparent Barrett's neoplasia: A prospective, randomized, double-blind, controlled, crossover trial. Gastrointest Endosc 2010;72:668.

58. Bertani H, Frazzoni M, Dabizzi E, Pigò F, Losi L, Manno M, et al. Improved detection of incident dysplasia by probe-based confocal laser endomicroscopy in a Barrett's esophagus surveillance program. Dig Dis Sci 2013;58:188-93.

59. Shahid MW, Wallace MB. Endoscopic imaging for the detection of esophageal dysplasia and carcinoma. Gastrointest Endosc Clin N Am 2010;20:11-24

60. Canto MI, Anandasabapathy S, Brugge W, Falk GW, Dunbar KB, Zhang Z, et al. In vivo endomicroscopy improves detection of Barrett's esophagus-related neoplasia: A multicenter international randomized controlled trial (with video). Gastrointest Endosc 2014;79:211-21.

61. Wallace MB, Sharma P, Lightdale C, Wolfsen H, Coron E, Buchner A, et al. Preliminary accuracy and interobserver agreement for the detection of intraepithelial neoplasia in Barrett's esophagus with probe-based confocal laser endomicroscopy. Gastrointest Endosc 2010;72:19-24

62. Pohl H, Rosch T, Vieth M, Koch M, Becker V, Anders M, et al. Miniprobe confocal laser microscopy for the detection of invisible neoplasia in patients with Barrett's oesophagus. Gut 2008:57:1648-53.

63. Sharma P, Meining AR, Coron E, Lightdale CJ, Wolfsen HC, Bansal A, Bajbouj M, et al. Real-time increased detection of neoplastic tissue in
Barrett's esophagus with probe-based confocal laser endomicroscopy: Final results of an international multicenter, prospective, randomized, controlled trial. Gastrointest Endosc 2011;74:465-72.

64. Gaddam S, Mathur SC, Singh M, Arora J, Wani SB, Gupta N, et al Novel probe-based confocal laser endomicroscopy criteria and interobserver agreement for the detection of dysplasia in Barrett's esophagus. Am J Gastroenterol 2011;106:1961-9.

65. Wallace MB, Crook JE, Saunders M, LOvat L, Coron E, Waxman I, et al. Multicenter, randomized, controlled trial of confocal laser endomicroscopy assessment of residual metaplasia after mucosal ablation or resection of GI neoplasia in Barrett's esophagus. Gastrointest Endosc 2012;76:539-47 e1.

66. Wallace M, Lauwers GY, Chen Y, Dekker E, Fockens P, Sharma P, et al. Miami classification for probe-based confocal laser endomicroscopy. Endoscopy 2011;43:882-91.

67. Bergman JJ, Tytgat GN. New developments in the endoscopic surveillance of Barrett's oesophagus. Gut 2005;54(Supl. 1):i38-42.

68. Curvers WL, Herrero LA, Wallace MB, Wong Kee Song LM, Ragunath $\mathrm{K}$, Wolfsen $\mathrm{HC}$, et al. Endoscopic tri-modal imaging is more effective than standard endoscopy in identifying early-stage neoplasia in Barrett's esophagus. Gastroenterology 2010;139:1106-14.

69. Kara MA, Peters FP, Ten Kate FJ, Van Deventer SJ, Fockens P, Bergman JJ. Endoscopic video autofluorescence imaging may improve the detection of early neoplasia in patients with Barrett's esophagus. Gastrointest Endosc 2005;61:679-85.

70. Curvers WL, Singh R, Song LM, Wolfsen HC, Ragunath K, Wang $\mathrm{K}$, et al. Endoscopic tri-modal imaging for detection of early neoplasia in Barrett's oesophagus: A multi-centre feasibility study using high-resolution endoscopy, autofluorescence imaging and narrow band imaging incorporated in one endoscopy system. Gut 2008;57:167-72.

71. Committee AT. Enhanced imaging in the GI tract: Spectroscopy and optical coherence tomography. Gastrointest Endosc 2013;78:568-73.

72. Kendall C, Stone N, Shepherd N, Geboes K, Warren B, Bennett R, et al. Raman spectroscopy, a potential tool for the objective identification and classification of neoplasia in Barrett's oesophagus. J Pathol 2003;200:602-9.

73. Douplik A, Zanati S, Saiko G, Streutker C, Loshchenov M, Adler D, et al. Diffuse reflectance spectroscopy in Barrett's esophagus: Developing a large field-of-view screening method discriminating dysplasia from metaplasia. J Biophotonics 2012 Nov 2. doi: 10.1002/jbio.201200114.

74. 74. Konda VJ, Cherkezyan L, Subramanian H, Wroblewski K, Damania D, Becker V, et al. Nanoscale markers of esophageal field carcinogenesis: Potential implications for esophageal cancer screening. Endoscopy 2013;45:983-8.

75. Fujimoto JG, Pitris C, Boppart SA, Brezinski ME. Optical coherence tomography: An emerging technology for biomedical imaging and optical biopsy. Neoplasia 2000;2:9-25.

76. Isenberg G, Sivak MV, Jr., Chak A, Wong RC, Willis JE, Wolf B, et al. Accuracy of endoscopic optical coherence tomography in the detection of dysplasia in Barrett's esophagus: A prospective, double-blinded study. Gastrointest Endosc 2005;62:825-31.

77. Evans JA, Poneros JM, Bouma BE, Bressner J, Halpern EF, Shiskov $\mathrm{M}$, et al. Optical coherence tomography to identify intramucosal carcinoma and high-grade dysplasia in Barrett's esophagus. Clin Gastroenterol Hepatol 2006;4:38-43.

78. Poneros JM, Brand S, Bouma BE, Tearney GJ, Compton CC, Nishioka NS. Diagnosis of specialized intestinal metaplasia by optical coherence tomography. Gastroenterology 2001;120:7-12.

79. Zhou C, Tsai TH, Lee HC, Kirtane T, Figueiredo M, Tao YK, et al Characterization of buried glands before and after radiofrequency ablation by using 3-dimensional optical coherence tomography (with videos). Gastrointest Endosc 2012;76:32-40.

80. Adler DC, Zhou C, Tsai TH, Lee HC, Becker L, Schmitt JM, et al. Three-dimensional optical coherence tomography of Barrett's esophagus and buried glands beneath neosquamous epithelium following radiofrequency ablation. Endoscopy 2009;41:773-6.

81. Edge SB, Byrd DR, Compton CC, et al. editors. American Joint Committee on Cancer Staging Manual. 7th ed. New York: Springer; 2010. p. 103.

82. Flejou JF, Svrcek M. Barrett's oesophagus -a pathologist's view. Histopathology 2007:50:3-14

83. Rice TW, Zuccaro G, Jr., Adelstein DJ, Rybicki LA, Blackstone EH, Goldblum JR. Esophageal carcinoma: Depth of tumor invasion is pre- 
dictive of regional lymph node status. Ann Thorac Surg 1998;65:78792.

84. Feith M, Stein HJ, Siewert JR. Pattern of lymphatic spread of Barrett's cancer. World J Surg 2003;27:1052-7.

85. Wang VS, Hornick JL, Sepulveda JA, Mauer R, Poneros JM. Low prevalence of submucosal invasive carcinoma at esophagectomy for high-grade dysplasia or intramucosal adenocarcinoma in Barrett's esophagus: A 20-year experience. Gastrointest Endosc 2009;69:77783.

86. Dunbar KB, Spechler SJ. The risk of lymph-node metastases in patients with high-grade dysplasia or intramucosal carcinoma in Barrett's esophagus: A systematic review. Am J Gastroenterol 2012;107:85062; quiz 63

87. Bollschweiler E, Baldus SE, Schroder W, Prenzel K, Gutschow C, Schneider PM, et al. High rate of lymph-node metastasis in submucosal esophageal squamous-cell carcinomas and adenocarcinomas. Endoscopy 2006;38:149-56.

88. Stolte M, Kirtil T, Oellig F, Vogel C, Mueller H, May A, et al. The pattern of invasion of early carcinomas in Barrett's esophagus is dependent on the depth of infiltration. Pathol Res Pract 2010;206:300-4.

89. Pellegrini CA, Pohl D. High-grade dysplasia in Barrett's esophagus: Surveillance or operation? J Gastrointest Surg 2000;4:131-4.

90. Ferguson MK, Naunheim KS. Resection for Barrett's mucosa with high-grade dysplasia: Implications for prophylactic photodynamic therapy. J Thorac Cardiovasc Surg 1997;114:824-9.

91. Konda VJ, Ross AS, Ferguson MK, Hart JA, Lin S, Naylor K, et al. Is the risk of concomitant invasive esophageal cancer in high-grade dysplasia in Barrett's esophagus overestimated? Clin Gastroenterol Hepatol 2008;6:159-64.

92. Pech O, Behrens A, May A, Nachbar L, Gossner L, Rabenstein T, et al. Long-term results and risk factor analysis for recurrence after curative endoscopic therapy in 349 patients with high-grade intraepithelial neoplasia and mucosal adenocarcinoma in Barrett's oesophagus. Gut 2008:57:1200-6.

93. Chennat J, Konda VJ, Ross AS, de Tejada AH, Noffsinger A, Hart J, et al. Complete Barrett's eradication endoscopic mucosal resection: An effective treatment modality for high-grade dysplasia and intramucosal carcinoma -an American single-center experience. Am J Gastroenterol 2009; 104:2684-92.

94. Gasper WJ, Glidden DV, Jin C, Way LW, Patti MG. Has recognition of the relationship between mortality rates and hospital volume for major cancer surgery in California made a difference?: A follow-up analysis of another decade. Ann Surg 2009;250:472-83.

95. Swisher SG, Deford L, Merriman KW, Walsh GL, Smythe R, Vaporicyan A, et al. Effect of operative volume on morbidity, mortality, and hospital use after esophagectomy for cancer. J Thorac Cardiovasc Surg 2000;119:1126-32.

96. Tharavej C, Hagen JA, Peters JH, Portale G, Lipham J, DeMeester SR, et al. Predictive factors of coexisting cancer in Barrett's high-grade dysplasia. Surg Endosc 2006;20:439-43.

97. Ortiz-Fernandez-Sordo J, Parra-Blanco A, Garcia-Varona A, Rodriguez-Pelaez M, Madrigal-Hoyos E, Waxman I, et al. Endoscopic resection techniques and ablative therapies for Barrett's neoplasia. World J Gastrointest Endosc 2011;3:171-82.

98. Update on the paris classification of superficial neoplastic lesions in the digestive tract. Endoscopy 2005;37:570-8.

99. Peters FP, Brakenhoff KP, Curvers WL, Rosmolen WD, Fockens P, ten Kate FJ, et al. Histologic evaluation of resection specimens obtained at 293 endoscopic resections in Barrett's esophagus. Gastrointest Endosc 2008;67:604-9.

100. Waxman I, Konda VJ. Mucosal ablation of Barrett esophagus. Nat Rev Gastroenterol Hepatol 2009;6:393-401

101. Mino-Kenudson M, Hull MJ, Brown I, Muzikansky A, Srivastava A, Glickman J, et al. EMR for Barrett's esophagus-related superficial neoplasms offers better diagnostic reproducibility than mucosal biopsy. Gastrointest Endosc 2007;66:660-6; quiz 767, 9.

102. Moss A, Bourke MJ, Hourigan LF, Gupta S, Williams SJ, Tran K, et al. Endoscopic resection for Barrett's high-grade dysplasia and early esophageal adenocarcinoma: An essential staging procedure with longterm therapeutic benefit. Am J Gastroenterol 2010;105:1276-83.

103. Hull MJ, Mino-Kenudson M, Nishioka NS, Ban S, Sepehr A, Puricelli W, et al. Endoscopic mucosal resection: An improved diagnostic procedure for early gastroesophageal epithelial neoplasms. Am J Surg Pathol 2006;30:114-8.

104. Prasad GA, Buttar NS, Wongkeesong LM, Lewis JT, Sanderson SO, Lutzke LS, et al. Significance of neoplastic involvement of margins obtained by endoscopic mucosal resection in Barrett's esophagus. Am J Gastroenterol 2007;102:2380-6.

105. Chennat J, Waxman I. Endoscopic treatment of Barrett's esophagus: From metaplasia to intramucosal carcinoma. World J Gastroenterol 2010;16:3780-5

106. Albéniz Arbizu E, Pueyo Royo A, Eguaras Ros J, Casi Villarroya, MA Ruiz-Clavijo García D, Oquiñena Legaz S, et al Resección endoscópica mucosa de lesiones superficiales altas: Endoscopic mucosal resection for proximal superficial lesions: Efficacy and safety study in 59 consecutive resections. Rev Esp Enferm Dig 2012;104:458-67.

107. May A, Gossner L, Behrens A, Kohnen R, Vieth M, Stolte M, et al. A prospective randomized trial of two different endoscopic resection techniques for early stage cancer of the esophagus. Gastrointest Endosc 2003;58:167-75.

108. Alvarez Herrero L, Pouw RE, van Vilsteren FG, ten Kate FJ, Visser M, Seldenrijk CA, et al. Safety and efficacy of multiband mucosectomy in 1060 resections in Barrett's esophagus. Endoscopy 2010;43:177-83.

109. Ell C, May A, Pech O, Gossner L, Guenter E, Behrens A, et al. Curative endoscopic resection of early esophageal adenocarcinomas (Barrett's cancer). Gastrointest Endosc 2007;65:3-10.

110. Manner H, May A, Pech O, Gossner L, Rabenstein T, Günter E, et al. Early Barrett's carcinoma with "low-risk" submucosal invasion: Long-term results of endoscopic resection with a curative intent. Am J Gastroenterol 2008;103:2589-97.

111. Ell C, May A, Gossner L, Pech O, Günter E, Mayer G, et al. Endoscopic mucosal resection of early cancer and high-grade dysplasia in Barrett's esophagus. Gastroenterology 2000;118:670-7.

112. Peters FP, Brakenhoff KP, Curvers WL, Rosmolen WD, ten Kate FJ, Krishnadath KK, et al. Endoscopic cap resection for treatment of early Barrett's neoplasia is safe: A prospective analysis of acute and early complications in 216 procedures. Dis Esophagus 2007;20:510-5.

113. Alvarez Herrero L, Pouw RE, van Vilsteren FG, ten Kate FJ, Visser M, Seldenrijk CA, et al. Safety and efficacy of multiband mucosectomy in 1060 resections in Barrett's esophagus. Endoscopy 2011;43:177-83.

114. Mino-Kenudson M, Brugge WR, Puricelli WP, Nakatsuka LN, Nishioka NS, Zukerberg LR, et al. Management of superficial Barrett's epithelium-related neoplasms by endoscopic mucosal resection: Clinicopathologic analysis of 27 cases. Am J Surg Pathol 2005;29:680-6.

115. Buttar NS, Wang KK, Sebo TJ, Riehle DM, Krishnadath KK, Lutzke LS, et al. Extent of high-grade dysplasia in Barrett's esophagus correlates with risk of adenocarcinoma. Gastroenterology 2001;120:1630-9.

116. May A, Gossner L, Pech O, Müller H, Vieth M, Stolte M, et al. Intraepithelial high-grade neoplasia and early adenocarcinoma in short-segment Barrett's esophagus (SSBE): Curative treatment using local endoscopic treatment techniques. Endoscopy 2002;34:604-10.

117. Hage M, Siersema PD, Vissers KJ, Steyerberg EW, Haringsma J, Kuipers EJ, et al. Molecular evaluation of ablative therapy of Barrett's oesophagus. J Pathol 2005;205:57-64.

118. Peters FP, Kara MA, Rosmolen WD, ten Kate FJ, Krishnadath KK, van Lanschot JJ, et al. Stepwise radical endoscopic resection is effective for complete removal of Barrett's esophagus with early neoplasia: A prospective study. Am J Gastroenterol 2006;101:1449-57.

119. Lopes CV, Hela M, Pesenti C, Bories E, Caillol F, Monges G, et al. Circumferential endoscopic resection of Barrett's esophagus with highgrade dysplasia or early adenocarcinoma. Surg Endosc 2007;21:820-4.

120. Larghi A, Lightdale CJ, Ross AS, Fedi P, Hart J, Rotterdam H, et al. Long-term follow-up of complete Barrett's eradication endoscopic mucosal resection (CBE-EMR) for the treatment of high grade dysplasia and intramucosal carcinoma. Endoscopy 2007;39:1086-91.

121. Pouw RE, Seewald S, Gondrie JJ, Deprez PH, Piessevaux H, Pohl H, et al. Stepwise radical endoscopic resection for eradication of Barrett's oesophagus with early neoplasia in a cohort of 169 patients. Gut 2010;59:1169-77.

122. Gerke H, Siddiqui J, Nasr I, Van Handel DM, Jensen CS. Efficacy and safety of EMR to completely remove Barrett's esophagus: Experience in 41 patients. Gastrointest Endosc 2011;74:761-71.

123. van Vilsteren FG, Pouw RE, Seewald S, Alvarez Herrero L, Sondermeijer CM, Visser M, et al. Stepwise radical endoscopic resection 
versus radiofrequency ablation for Barrett's oesophagus with highgrade dysplasia or early cancer: A multicentre randomised trial. Gut 2011;60:765-73.

124. Lewis JJ, Rubenstein JH, Singal AG, Elmunzer BJ, Kwon RS, Piraka CR. Factors associated with esophageal stricture formation after endoscopic mucosal resection for neoplastic Barrett's esophagus. Gastrointest Endosc 2011;74:753-60.

125. Zeki SS, Haidry R, Graham TA, Rodriguez-Justo M, Novelli M, Hoare $\mathrm{J}$, et al. Clonal selection and persistence in dysplastic Barrett's esophagus and intramucosal cancers after failed radiofrequency ablation. Am J Gastroenterol 2013;108:1584-92.

126. Toyonaga T, Man-i M, East JE, Nishino E, Ono W, Hirooka T, et al. 1,635 Endoscopic submucosal dissection cases in the esophagus, stomach, and colorectum: Complication rates and long-term outcomes. Surg Endosc 2013;27:1000-8.

127. Saito Y, Fukuzawa M, Matsuda T, Fukunaga S, Sakamoto T, Uraoka $\mathrm{T}$, et al. Clinical outcome of endoscopic submucosal dissection versus endoscopic mucosal resection of large colorectal tumors as determined by curative resection. Surg Endosc 2010;24:343-52.

128. 128. Cao Y, Liao C, Tan A, Gao Y, Mo Z, Gao F. Meta-analysis of endoscopic submucosal dissection versus endoscopic mucosal resection for tumors of the gastrointestinal tract. Endoscopy 2009;41:751-7.

129. Yoshinaga S, Gotoda T, Kusano C, Oda I, Nakamura K, Takayanagi R. Clinical impact of endoscopic submucosal dissection for superficial adenocarcinoma located at the esophagogastric junction. Gastrointest Endosc 2008:67:202-9.

130. Omae M, Fujisaki J, Horiuchi Y, Yoshizawa N, Matsuo Y, Kubota M, et al. Safety, efficacy, and long-term outcomes for endoscopic submucosal dissection of early esophagogastric junction cancer. Gastric Cancer 2013;16:147-54.

131. Ishihara R, Iishi H, Uedo N, Takeuchi Y, Yamamoto S, Yamada T, et al. Comparison of EMR and endoscopic submucosal dissection for en bloc resection of early esophageal cancers in Japan. Gastrointest Endosc 2008;68:1066-72

132. Sgourakis G, Gockel I, Lang H. Endoscopic and surgical resection of T1a/T1b esophageal neoplasms: A systematic review. World J Gastroenterol 2013;19:1424-37.

133. Yamaguchi Y, Katusmi N, Aoki K, Toki M, Nakamura K, Abe N, et al. Resection area of $15 \mathrm{~mm}$ as dividing line for choosing strip biopsy or endoscopic submucosal dissection for mucosal gastric neoplasm. J Clin Gastroenterol 2007;41:472-6.

134. Koike T, Nakagawa K, Iijima K, Shimosegawa T. Endoscopic resection (endoscopic submucosal dissection/endoscopic mucosal resection) for superficial Barrett's esophageal cancer. Dig Endosc 2013;25 Suppl $1: 20-8$.

135. Parra-Blanco A, Arnau MR, Nicolas-Perez D, Gimeno-Garcia AZ, Gonzalez N, Diaz-Acosta JA, et al. Endoscopic submucosal dissection training with pig models in a Western country. World J Gastroenterol 2010;16:2895-900.

136. Deprez PH, Bergman JJ, Meisner S, Ponchon T, Repici A, Dinis. Ribeiro M, et al. Current practice with endoscopic submucosal dissection in Europe: Position statement from a panel of experts. Endoscopy 2010;42:853-8

137. Kwon CI. Endoscopic submucosal dissection (ESD) training and performing ESD with Accurate and safe techniques. Clin Endosc 2012;45:347-9.

138. Neuhaus H, Terheggen G, Rutz EM, Vieth M, Schumacher B. Endoscopic submucosal dissection plus radiofrequency ablation of neoplastic Barrett's esophagus. Endoscopy 2012;44:1105-13.

139. Pohl H, Sonnenberg A, Strobel S, Eckardt A, Rosch T. Endoscopic versus surgical therapy for early cancer in Barrett's esophagus: A decision analysis. Gastrointest Endosc 2009;70:623-31.

140. Fernandez-Sordo JO, Konda VJ, Chennat J, Madrigal-Hoyos E, Posner MC, Fergusson MK, et al. Is Endoscopic Ultrasound (EUS) necessary in the pre-therapeutic assessment of Barrett's esophagus with early neoplasia? J Gastrointest Oncol 2012;3:314-21.

141. Larghi A, Lightdale CJ, Memeo L, Bhagat G, Okpara N, Rotterdam H. EUS followed by EMR for staging of high-grade dysplasia and early cancer in Barrett's esophagus. Gastrointest Endosc 2005;62:16-23.

142. Pech O, May A, Gunter E, Gossner L, Ell C. The impact of endoscopic ultrasound and computed tomography on the TNM staging of early cancer in Barrett's esophagus. Am J Gastroenterol 2006;101:2223-9.
143. Waxman I, Raju GS, Critchlow J, Antonioli DA, Spechler SJ. Highfrequency probe ultrasonography has limited accuracy for detecting invasive adenocarcinoma in patients with Barrett's esophagus and high-grade dysplasia or intramucosal carcinoma: A case series. Am J Gastroenterol 2006;101:1773-9.

144. Fleischer DE, Sharma VK. Endoscopic ablation of Barrett's esophagus using the Halo system. Dig Dis 2008;26:280-4.

145. Fleischer DE, Overholt BF, Sharma VK, Reymunde A, Kimmey MB, Chuttani R, et al. Endoscopic ablation of Barrett's esophagus: A multicenter study with 2.5-year follow-up. Gastrointest Endosc 2008;68:867-76.

146. Ganz RA, Overholt BF, Sharma VK, Fleisher DE, Saheen NJ, Lightdale CJ, et al. Circumferential ablation of Barrett's esophagus that contains high-grade dysplasia: A U.S. Multicenter Registry. Gastrointest Endosc 2008;68:35-40.

147. Sharma VK, Jae Kim H, Das A, Wells CD, Nguyen CC, Fleischer DE. Circumferential and focal ablation of Barrett's esophagus containing dysplasia. Am J Gastroenterol 2009;104:310-7.

148. Lyday WD, Corbett FS, Kuperman DA, Kalvaria I, Mavrelis PG, Shughoury $\mathrm{AB}$, et al. Radiofrequency ablation of Barrett's esophagus: Outcomes of 429 patients from a multicenter community practice registry. Endoscopy 2010;42:272-8.

149. Pouw RE, Wirths K, Eisendrath P, Sondermeijer CM, Ten Kate FJ, Fockens P, et al. Efficacy of radiofrequency ablation combined with endoscopic resection for barrett's esophagus with early neoplasia. Clin Gastroenterol Hepatol 2010;8:23-9.

150. Shaheen NJ, Sharma P, Overholt BF, Wolfsen HC, Sampliner RE, Wang KK, et al. Radiofrequency ablation in Barrett's esophagus with dysplasia. N Engl J Med 2009;360:2277-88.

151. Shaheen NJ, Overholt BF, Sampliner RE, Wolfsen HC, Wang KK, Fleischer DE, et al. Durability of radiofrequency ablation in Barrett's esophagus with dysplasia. Gastroenterology 2011;141:460-8.

152. Fleischer DE, Overholt BF, Sharma VK, Reymunde A, Kimmey MB, Chuttani R, et al. Endoscopic radiofrequency ablation for Barrett's esophagus: 5-year outcomes from a prospective multicenter trial. Endoscopy 2010;42:781-9.

153. Haidry RJ, Dunn JM, Butt MA, Burnell MG, Gupta A, Green S, et al. Radiofrequency ablation and endoscopic mucosal resection for dysplastic barrett's esophagus and early esophageal adenocarcinoma: Outcomes of the UK National Halo RFA Registry. Gastroenterology 2013;145:87-95

154. Gupta M, Iyer PG, Lutzke L, Gorospe EC, Abrams JA, Falk GW, et al. Recurrence of esophageal intestinal metaplasia after endoscopic mucosal resection and radiofrequency ablation of Barrett's esophagus: Results from a US Multicenter Consortium. Gastroenterology 2013; 145:79-86 e1.

155. Bulsiewicz WJ, Kim HP, Dellon ES, Cotton CC, Pasricha S, Madanick $\mathrm{RD}$, et al. Safety and efficacy of endoscopic mucosal therapy with radiofrequency ablation for patients with neoplastic Barrett's esophagus. Clin Gastroenterol Hepatol 2013;11:636-42.

156. Phoa KN, Pouw RE, van Vilsteren FG, Sondermeijer CM, Ten Kate FJ, Visser M, et al. Remission of Barrett's esophagus with early neoplasia 5 years after radiofrequency ablation with endoscopic resection: A Netherlands cohort study. Gastroenterology 2013;145:96-104.

157. Orman ES, Li N, Shaheen NJ. Efficacy and durability of radiofrequency ablation for Barrett's Esophagus: Systematic review and metaanalysis. Clin Gastroenterol Hepatol 2013;11:1245-55.

158. Okoro NI, Tomizawa Y, Dunagan KT, Lutzke LS, Wang KK, Prasad GA. Safety of prior endoscopic mucosal resection in patients receiving radiofrequency ablation of Barrett's esophagus. Clin Gastroenterol Hepatol 2012;10:150-4.

159. Kim HP, Bulsiewicz WJ, Cotton CC, Dellon ES, Spacek MB, Chen $\mathrm{X}$, et al. Focal endoscopic mucosal resection before radiofrequency ablation is equally effective and safe compared with radiofrequency ablation alone for the eradication of Barrett's esophagus with advanced neoplasia. Gastrointest Endosc 2012;76:733-9.

160. Krishnan K, Pandolfino JE, Kahrilas PJ, Keefer L, Boris L, Komanduri $\mathrm{S}$. Increased risk for persistent intestinal metaplasia in patients with Barrett's esophagus and uncontrolled reflux exposure before radiofrequency ablation. Gastroenterology 2012;143:576-81.

161. Dulai PS, Pohl H, Levenick JM, Gordon SR, MacKenzie TA, Rothstein RI. Radiofrequency ablation for long- and ultralong-segment Barrett's 
esophagus: a comparative long-term follow-up study. Gastrointest Endosc 2013;77:534-41.

162. Hur C, Choi SE, Rubenstein JH, Kong CY, Nishioka NS, Provenzale DT, et al. The cost effectiveness of radiofrequency ablation for Barrett's esophagus. Gastroenterology 2012;143:567-75.

163. Inadomi JM, Somsouk M, Madanick RD, Thomas JP, Shaheen NJ. A cost-utility analysis of ablative therapy for Barrett's esophagus. Gastroenterology 2009;136:2101-14 e1-6.

164. Shaheen NJ, Inadomi JM, Overholt BF, Sharma P. What is the best management strategy for high grade dysplasia in Barrett's oesophagus? A cost effectiveness analysis. Gut 2004;53:1736-44.

165. Overholt BF, Wang KK, Burdick JS, Lightdale CJ, Kimmey M, Nava HR, et al. Five-year efficacy and safety of photodynamic therapy with Photofrin in Barrett's high-grade dysplasia. Gastrointest Endosc 2007;66:460-8

166. Pech O, Gossner L, May A, Rabenstein T, Vieth M, Stolte M, et al. Long-term results of photodynamic therapy with 5-aminolevulinic acid for superficial Barrett's cancer and high-grade intraepithelial neoplasia. Gastrointest Endosc 2005;62:24-30.

167. Vij R, Triadafilopoulos G, Owens DK, Kunz P, Sanders GD. Costeffectiveness of photodynamic therapy for high-grade dysplasia in Barrett's esophagus. Gastrointest Endosc 2004;60:739-56.

168. Gray NA, Odze RD, Spechler SJ. Buried metaplasia after endoscopic ablation of Barrett's esophagus: A systematic review. Am J Gastroenterol 2011;106:1899-908; quiz 909.

169. Ban S, Mino M, Nishioka NS, Puricelli W, Zukerberg LR, Shimizu M, et al. Histopathologic aspects of photodynamic therapy for dysplasia and early adenocarcinoma arising in Barrett's esophagus. Am J Surg Pathol 2004;28(11):1466-73.

170. Greenwald BD, Dumot JA. Cryotherapy for Barrett's esophagus and esophageal cancer. Curr Opin Gastroenterol 2011;27:363-7.

171. Greenwald BD, Dumot JA, Abrams JA, Lightdale CJ, David DS, Nishioka NS, et al. Endoscopic spray cryotherapy for esophageal cancer: Safety and efficacy. Gastrointest Endosc 2010;71:686-93.

172. Shaheen NJ, Greenwald BD, Peery AF, Dumot JA, Nishioka NS, Wolfsen HC, et al. Safety and efficacy of endoscopic spray cryotherapy for Barrett's esophagus with high-grade dysplasia. Gastrointest Endosc 2010;71:680-5.

173. Dumot JA, Vargo JJ, 2nd, Falk GW, Frey L, Lopez R, Rice TW. An open-label, prospective trial of cryospray ablation for Barrett's esophagus high-grade dysplasia and early esophageal cancer in high-risk patients. Gastrointest Endosc 2009;70:635-44.

174. Gosain S, Mercer K, Twaddell WS, Uradomo L, Greenwald BD. Liquid nitrogen spray cryotherapy in Barrett's esophagus with high-grade dysplasia: Long-term results. Gastrointest Endosc 2013; 78:260-5.

175. Sharma P, Wani S, Weston AP, Bansal A, Hall M, Mathur S, et al. A randomised controlled trial of ablation of Barrett's oesophagus with multipolar electrocoagulation versus argon plasma coagulation in combination with acid suppression: Long term results. Gut 2006;55:12339.

176. Mork H, Al-Taie O, Berlin F, Kraus MR, Scheurlen M. High recurrence rate of Barrett's epithelium during long-term follow-up after argon plasma coagulation. Scand J Gastroenterol 2007;42:23-7.
177. Bright T, Watson DI, Tam W, Game PA, Astill D, Ackroyd R, et al. Randomized trial of argon plasma coagulation versus endoscopic surveillance for barrett esophagus after antireflux surgery: Late results. Ann Surg 2007;246:1016-20.

178. Van Laethem JL, Peny MO, Salmon I, Cremer M, Deviere J. Intramucosal adenocarcinoma arising under squamous re-epithelialisation of Barrett's oesophagus. Gut 2000;46:574-7.

179. Gupta N, Mathur SC, Dumot JA, et al. Adequacy of esophageal squamous mucosa specimens obtained during endoscopy: Are standard biopsies sufficient for postablation surveillance in Barrett's esophagus? Gastrointest Endosc 2012;75:11-8.

180. Shaheen NJ, Peery AF, Overholt BF, Lightdale CJ, Chak A, Wang KK, et al. Biopsy depth after radiofrequency ablation of dysplastic Barrett's esophagus. Gastrointest Endosc 2010;72:490-6 e1.

181. Herrero LA, van Vilsteren FG, Pouw RE, ten Kate FJ, Visser M, Seldenrijk CA, et al. Endoscopic radiofrequency ablation combined with endoscopic resection for early neoplasia in Barrett's esophagus longer than $10 \mathrm{~cm}$. Gastrointest Endosc 2011;73:682-90.

182. Guarner-Argente C, Buoncristiano T, Furth EE, Falk GW, Ginsberg GG. Long-term outcomes of patients with Barrett's esophagus and high-grade dysplasia or early cancer treated with endoluminal therapies with intention to complete eradication. Gastrointest Endosc 2013;77:190-9.

183. Liu L, Hofstetter WL, Rashid A, Swisher SG, Correa AM, Ajani JA, et al. Significance of the depth of tumor invasion and lymph node metastasis in superficially invasive (T1) esophageal adenocarcinoma. Am J Surg Pathol 2005;29:1079-85.

184. Manner H, Pech O, Heldmann Y, May A, Pohl J, Behrens A, et al. Efficacy, safety, and long-term results of endoscopic treatment for early stage adenocarcinoma of the esophagus with low-risk sm1 invasion. Clin Gastroenterol Hepatol 2013;11:630-5; quiz e45.

185. 1Badreddine RJ, Prasad GA, Lewis JT, Lutzke LS, Borkenhagen LS, Dunagan KT, et al. Depth of submucosal invasion does not predict lymph node metastasis and survival of patients with esophageal carcinoma. Clin Gastroenterol Hepatol 2010;8:248-53.

186. Konda VJ, Ferguson MK. Esophageal resection for high-grade dysplasia and intramucosal carcinoma: When and how? World J Gastroenterol 2010;16:3786-92.

187. Birkmeyer JD, Siewers AE, Finlayson EV, Stukel TA, Lucas FL, Batista I, et al. Hospital volume and surgical mortality in the United States. N Engl J Med 2002;346:1128-37.

188. Prasad GA, Wu TT, Wigle DA, Buttar NS, Wongkeesong LM, Dunagan KT, et al. Endoscopic and surgical treatment of mucosal (T1a) esophageal adenocarcinoma in Barrett's esophagus. Gastroenterology 2009; 137:815-23.

189. Meguid RA, Weiss ES, Chang DC, Brock MV, Yang SC. The effect of volume on esophageal cancer resections: What constitutes acceptable resection volumes for centers of excellence? J Thorac Cardiovasc Surg 2009;137:23-9.

190. van Lanschot JJ, Hulscher JB, Buskens CJ, Tilanus HW, ten Kate FJ, Obertop H. Hospital volume and hospital mortality for esophagectomy. Cancer 2001;91:1574-8.

191. Dimick JB, Pronovost PJ, Cowan JA, Lipsett PA. Surgical volume and quality of care for esophageal resection: do high-volume hospitals have fewer complications? Ann Thorac Surg 2003;75:337-41. 